\title{
Cardiovascular Disease Hospitalizations in Louisiana Parishes' Elderly before, during and after Hurricane Katrina
}

\author{
Ninon A. Becquart ${ }^{1,+}$, Elena N. Naumova ${ }^{2,3, *,+}$, Gitanjali Singh ${ }^{2}$ and Kenneth K. H. Chui ${ }^{2,3}$ \\ 1 Sackler School of Graduate Biomedical Sciences, Tufts University, Boston, MA 02111, USA; \\ Ninon.Becquart@tufts.edu \\ 2 Friedman School of Nutrition Science and Policy, Tufts University, Boston, MA 02111, USA; \\ gitanjali.singh@tufts.edu (G.S.); kenneth.chui@tufts.edu (K.K.H.C.) \\ 3 School of Medicine, Tufts University, Boston, MA 02111, USA \\ * Correspondence: elena.naumova@tufts.edu \\ $\dagger$ These two authors contributed equally.
}

Received: 14 November 2018; Accepted: 22 December 2018; Published: 28 December 2018

\begin{abstract}
The research on how health and health care disparities impact response to and recovery from a disaster, especially among diverse and underserved populations is in great need for a thorough evaluation. The time series analysis utilizing most complete national databases of medical records is an indispensable tool in assessing the destruction and health toll brought about by natural disasters. In this study, we demonstrated such an application by evaluating the impact of Hurricane Katrina in 2005 on cardiovascular disease (CVD), a primary cause of mortality among older adults that can be aggravated by natural disasters. We compared CVD hospitalizations before, during and after Katrina between white and black residents of three most populated parishes in Louisiana: Orleans and Jefferson, which were severely affected by the landfall and subsequent floods, and East Baton Rouge, which hosted many of the evacuees. We abstracted 383,552 CVD hospitalization records for Louisiana's patients aged 65+ in 2005-2006 from the database maintained by the Center of Medicare \& Medicaid Services. Daily time series of CVD-related hospitalization rates at each study parish were compiled, and the changes were characterized using segmented regression. In Orleans Parish, directly affected by the hurricane, hospitalization rates peaked on the 6th day after landfall with an increase (mean \pm SD) from $7.25 \pm 2.4$ to $18.5 \pm 17.3$ cases/day per 10,000 adults aged $65+(p<0.001)$ and returned to pre-landfall level after $\sim 2$ months. Disparities in CVD rates between black and white older adults were exacerbated during and following landfall. In Orleans Parish, a week after landfall, the CVD rates increased to $26.3 \pm 23.7$ and $16.6 \pm 11.7$ cases/day per 10,000 people $(p<0.001)$ for black and white patients, respectively. The abrupt increase in CVDs is likely due to psychosocial and post-traumatic stress caused by the disaster and inadequate response. Inequities in resource allocation and access have to be addressed in disaster preparation and mitigation.
\end{abstract}

Keywords: equity; elderly; hurricane Katrina; cardiovascular diseases; segmented regression

\section{Introduction}

The United Nation World Conference on Disaster Risk Reduction held in Sendai, Japan on 14-18 March 2015 enforced the Hyogo Framework for Action, approved by the 168 member-states in 2005, and presented the Sendai Declaration aiming to further improve the multipronged response to disasters [1]. The Declaration paid special attention to building community resilience, engaging and empowering vulnerable populations, including children, elderly, and individuals with special needs. The Bloomberg Business Magazine recently reported the cost of damages from Harvey, Irma, 
and Maria hurricanes at about $\$ 202.6$ billion [2], almost 100 times of $\$ 3.2$ billion funds that the Federal Emergency Management Agency (FEMA) has obligated to public assistance after Hurricane Katrina to repair and rebuild public infrastructure, such as bridges, roads, schools, hospitals and sewer treatment facilities [3-6].

Hurricane Katrina was a harrowing experience for those impacted on 29 August 2005, when it hit the Gulf Coast. Homes were destroyed, two million people were displaced, and survivors experienced health effects that could be long-lasting [7]. Orleans, Jefferson, and St. Bernard parishes were the most affected, containing $95 \%$ of Katrina's victims, and approximately $80 \%$ of New Orleans was flooded [8]. A 2011 technical report by the National Oceanic and Atmospheric Administration (NOAA) stated that Hurricane Katrina was the costliest hurricane of all time, and the third most deadly and intense since 1900 [9]. It set records for the greatest count of tropical storms and hurricanes and tied the record for the most major hurricanes in a 2-year period [9].

The storm disproportionately affected older adults, black Americans and low-income communities. There were an estimated 971 deaths in Louisiana as a result of Hurricane Katrina, and the earliest and most numerous deaths were seen in the elderly $[8,10]$. Almost half of all the deceased were older than 75 years old, and an additional $26 \%$ were of the ages 60 to 75 [11]. Besides deaths, the vulnerable elderly people were substantially overrepresented among the evacuees-a population potentially predisposed to a high level of psychological distress exacerbated by severe disaster exposure, lack of economic and social resources, and inadequacy in government response [9]. In Orleans Parish, the mortality rate for black residents aged 18 or order was 1.7 to 4 times greater than that of the white [8]. In New Orleans, damaged areas had higher proportions of black residents and poor households than undamaged areas ( $45.8 \%$ versus $26.4 \%$, and $20.9 \%$ versus $15.3 \%$, respectively) [7]. Possible reasons for such post-disaster racial health disparities included insufficient supply of medication and limited access to need resources. Analyses revealed that black respondents had a limited access to a 3-day supply of their medications and this difference could be due to prescription drug coverage in health insurance plans, as well as access and proximity to pharmacy [12].

The most recent hurricane seasons repeatedly demonstrated that the needs of the elderly population in the United States during and following a disaster were often neglected [13]. The study of nationally representative panel survey of older Americans indicated that older adults in lower income status had lower preparedness level than those in higher income [14]. Most disaster response models focus on acute injury treatment, environmental risk management, and infectious disease prevention [15]. However, interviews and focus groups with both providers and survivors' contrast with the need to also include continued care for survivors with chronic conditions such as cardiovascular disease [15]. Among the Katrina survivors, $41-74 \%$ had one or more chronic conditions [15]. These survivors could not obtain medications due to availability or affordability, were unable to access medical records onsite or at a distance, and had limited healthcare resulting from the most significant efflux of the healthcare workforce known in U.S. history $[7,15]$. It is also possible that CVD disproportionally affected black survivors: in general, compared to white patients, patients of color experience higher CVD rates and risk factors, encounter more barriers to diagnosis, are given lower quality healthcare, and endure worse health outcomes [16]. In addition, black patients experience lower cardiac intervention rates, lower admission rates, and shorter cardiac care unit stays compared to white patients [16].

The complex nature a disaster typically triggers a series of cascading responses peaking at different times and forming a unique signature of each event. Such signatures have been observed in many studies analyzing the health effects of natural disasters. A study analyzing the effect of a 2011 tsunami on acute decompensated heart failure (ADHF) reported a peak in the weekly number of ADHF cases 3 to 4 weeks following the tsunami, after which number of cases per week returned to pre-disaster level [17]. Acute coronary syndrome, stroke, and cardiopulmonary arrest, pulmonary thromboembolism, and infectious endocarditis cases exhibited both a rapid increase and decline, whereas heart failure cases remained significantly increased for up to 7 weeks after 
the earthquake $[18,19]$. Examining the consequences of Hurricane Sandy in 2012, researchers have detected increases in hospitalizations and deaths due to myocardial infarction and stroke during the 2 weeks after landfall, compared to the same 2 weeks from the 5 previous years [20]. An increase of acute myocardial infarctions (AMI) admissions during 3 years after Hurricane Katrina, as compared to the 2-year period before the storm was noted [21]. Another study demonstrated that, during the 6 years following Katrina, the number of admissions for AMI tripled [22]. Researchers inferred that the higher incidences of severe cardiovascular events observed during natural disasters could be attributed to elevated stress [23], greater physical activity, change in blood rheology, diminished attention or ability to address medical needs, and insufficient emergency services [20]. Researchers credit lack of food and medications, which were also a reported problem following Hurricane Katrina, a possible cause [17].

The difficulties with collecting information during and after disasters are well recognized; underserved communities typically suffered due to limited resources allocated to data collection. The research on how health and health care disparities impact response to and recovery from a disaster, especially among diverse and underserved populations is in great need for thorough evaluation. The utilization of national databases of medical claim of patients had illustrated a strong potential in assessing environmental impacts on vulnerable populations [24-26]. The Center of Medicare \& Medicaid Services (CMS) has been maintaining uniformly collected hospitalization records with a coverage rate of $\sim 98 \%$ of US adults aged 65 years old and older. The large scale and rapid progression of natural disasters limit opportunities for detailed data collection over time, yet the time series analysis of medical records can help in recreating the short-term and long-term responses at a refined temporal and geographical scale $[27,28]$.

The objective of this study is to compare the daily rates of CVD hospitalizations before, during, and after Hurricane Katrina among older adults of Louisiana using CMS records. We established the critical periods in CVD responses to Katrina and examined hospitalization rates for black and white residents in three communities using segmented regression models adapted to time series analysis. We selected three parishes (equivalent to "counties" in other states): Orleans and Jefferson, two densely populated parishes most affected by the landfall and subsequent floods due to being on the storm track as well as East Baton Rouge-the parish that accommodated many evacuees [29]. We hypothesized that there was a significant difference in the number of cases, rates, and in the demographic profiles for the different periods. We also hypothesized that black elderly adults would be disproportionately impacted by the storm, as seen through higher CVD rates compared to white adults. While studies on the effects of natural disasters, including earthquakes on CVD exist, those focusing on hurricanes are sparse [20]. This is therefore one of the few studies analyzing the effect of hurricanes on CVD specifically. Results from this study can help further our understanding of natural disaster impacts on CVD and help health authorities better prepare for upcoming seasonal events. Our long-term goal is to pave the way for a solid methodology in assessing the impact of a disaster in order to better understand the cardiovascular needs of our elderly population and to ultimately advance disaster planning and long-term recovery efforts.

\section{Materials and Methods}

\subsection{CVD Records}

Medical claims were obtained from the Centers for Medicare and Medicaid Services (CMS). For the USA, 21,363,136 records of CVD hospitalizations were retrieved from the database in SQL Server 2014 Management Studio for all relevant International Classification of Diseases, Ninth Revision, Clinical Modification (ICD-9M CM) codes in any of 9 diagnostic fields for patients aged 65 and older from 1 January 2005 to 31 December 2006. The codes included: 390-398, 401-407, 420-438, 440-449, 451-459. In Louisiana, there were 383,552 hospitalizations, including 119,612 cases with CVD listed as primary diagnoses. The distribution of specific sub-codes is shown in Appendix A Table A1. Of all the selected records, 17,769 were for Orleans Parish, 21,499 for Jefferson Parish, and 24,699 for East 
Baton Rouge Parish. Each record contained information on date of admission, sex, age, race, county and zip code of residence. Based on the county code of residence, we compiled counts for each county in the state of Louisiana. (Note, that in Louisiana, a "parish" is equivalent to a "county," which is a more generic term, so both terms can be used interchangeably.) We intentionally removed the first 6 days and the last 12 days to reduce the error associated with incomplete reporting at the beginning and at the end of the study period. Therefore, we reduced the study period to 710 days from 7 January 2005 to 17 December 2006. Based on the date of admission and patient's race, we compiled time series of daily counts for the study period for three selected counties or parishes (Orleans: 17,394 cases, Jefferson: 21,057, and East Baton Rouge: 24,147 cases) for black, white and all adults aged 65 or above (see Appendix A Table A2 for an example of the first 10 rows; full data set is available on request).

\subsection{Census Data and Hospitalization Rates}

Census data for the population 65 years and older on the County level was obtained from Census.gov for years 2005 and 2006. Because these are not Census years, American Community Survey (ACS) estimates and Intercensal estimates were used to supplement the Census data [30]. Hospitalization rates were calculated for spatial mapping and temporal analysis. For spatial mapping county-specific hospitalization rates were calculated by dividing counts of CVD cases per day for all period, pre-Katrina and post-Katrina periods by the parish population (65+) with the multiplier of 100,000. For temporal analysis, for each of the three parishes the daily hospitalization rates were calculated by dividing counts of CVD cases per day by the interpolated estimates of parish population with the multiplier of 10,000. The 2005 population counts were used for the period from 7 January 2005 to 29 August 2005, the day that Hurricane Katrina struck the Gulf coast. Hurricane Katrina caused a mass exodus of people from Orleans Parish and the surrounding area. Following Hurricane Katrina, it was more reasonable to use the 2006 population counts to reflect the loss or gain in population in a parish.

\subsection{Mapping}

We mapped the state of Louisiana populations by county, population density, daily hospitalization cases, and average daily hospitalization rates using ArcGIS 10.3.1 (Esri, Redlands, CA, USA). Because ACS estimates were not available for every parish in Louisiana, maps were produced with intercensal estimates for the whole study period, as well as pre- and post-Katrina's landfall periods (see Appendix A Table A3). Storm track was mapped using data from the Mississippi Automated Resource Information System (MARIS).

\subsection{Statistical Analysis}

Identifying critical periods using a loess smoother: A part of preliminary analysis, we superimposed daily time series of rates with a loess smoother [31] to assess the overall trend and weekly pattern:

$$
y_{t}=\beta_{0}+\beta_{1} l o(t, \alpha),
$$

where $y_{t}$ is CVD hospitalization rate at day $t, \beta_{0}$ represents the intercept, and $\beta_{1}$ represents the slope of the smoothed regression line. The study days were numbered from 1 to 710 (the total number of days being analyzed in the time series), starting from 7 January 2005 and ending on 17 December 2006. The span parameter $\alpha$ of the loess smoother lo(.) was selected to be equal to $7 / 710$ to reflect the weekly pattern that has also been previously reported for admissions due to AMI, a CVD subtype [22]. From the analysis of the Orleans Parish residents we identified six time period of interest to characterize the periods before evacuation, before the landfall, immediately after landfall, and recovery periods, which are also supported by reports about Katrina [32,33].

Segmented regression model: The study time period of 710 days divided into six intervals (T1, T2, T3, T4, T5, T6) were marked with knots, or endpoints: $a, b, c, d, e$ at days 225, 238, 247, 275, and 
303, respectively. Using the selected periods, we develop a segmented linear regression model [34], as follows:

$$
E\left(y_{t}\right)=\beta_{0}+\beta_{1} t+\beta_{2}(t-a)_{+}+\beta_{3}(t-b)_{+}+\beta_{4}(t-c)_{+}+\beta_{5}(t-d)_{+}+\beta_{6}(t-e)_{+}
$$

where

$$
(u)_{+}=\left\{\begin{array}{l}
u, u>0 \\
0, u \leq 0
\end{array}\right.
$$

Thus,

$$
\begin{array}{rlrl}
E\left(y_{t}\right) & =\beta_{0}+\beta_{1} t, & & t \leq a \\
& =\beta_{0}+\beta_{1} t+\beta_{2}(t-a) & & a<t \leq b \\
& =\beta_{0}+\beta_{1} t+\beta_{2}(t-a)+\beta_{3}(t-b) & & b<t \leq c \\
& =\beta_{0}+\beta_{1} t+\beta_{2}(t-a)+\beta_{3}(t-b)+\beta_{4}(t-c) & c<t \leq d \\
& =\beta_{0}+\beta_{1} t+\beta_{2}(t-a)+\beta_{3}(t-b)+\beta_{4}(t-c)+\beta_{5}(t-d) & & d<t \leq e \\
& =\beta_{0}+\beta_{1} t+\beta_{2}(t-a)+\beta_{3}(t-b)+\beta_{4}(t-c)+\beta_{5}(t-d)+\beta_{6}(t-e) & & e<t .
\end{array}
$$

This long expression can be summarized as follows:

$$
E\left(y_{t}\right)=\beta_{0}+\beta_{1} t+\sum_{t=1}^{t} \beta_{t+1}\left(t-(u)_{+}\right)_{+}
$$

where $(u)_{+}$are the locations of the break points, $y_{t}$ is CVD hospitalization rate at day $t$. The regression coefficients $\beta_{1}$ and $\beta_{2+}$ are the slopes for the selected time intervals.

Sensitivity analysis with a broken-stick model: As part of sensitivity analysis we estimated the intercept (or the value at the critical endpoints) and slope values using a broken-stick model for each pair of adjacent periods [35], as follow:

$$
E\left(y_{t}\right)=\beta_{0}+\beta_{1} t_{1}+\beta_{2} t_{2}
$$

where $y_{t}$ is daily CVD hospitalization rate, $t_{1}$ and $t_{2}$ represent the time for adjacent intervals, $\beta_{0}$ is the intercept, and $\beta_{1}$ and $\beta_{2}$ are the slopes for the adjacent time intervals. The results of the models along with the quality of fit are presented in Appendix A Table A4. The segmented model and the broken-stick model were run for total, black and white patients for each parish. All data processing and model building was done using $R$.

\section{Results}

For the 710-day study period, there were 383,552 hospitalizations due to CVD in Louisiana, including 119,612 cases with CVD listed as primary cause of hospitalization (Appendix A Table A1). The 420-429 ICD codes, referring to acute pericarditis, endocarditis, myocarditis, cardiomyopathy, conduction disorders, cardiac dysrhythmias, heart failure, and other complications of heart disease represented the majority (40\%) of CVD types for all subpopulations. For black patients, hospitalizations due to hypertensive heart diseases (401-405 ICD codes) were twice higher than for white patients ( $9.8 \%$ vs. $4.7 \%)$, in contrast with ischemic heart disease.

ACS-derived demographic data for each parish, or county of the state of Louisiana were mapped (Figure 1; data are provided in Appendix A Table A3). Figure 1 shows geographic distribution of population aged 65 and older and the average number of daily CVD cases per county (Panel A) and a close-up for the Orleans, Jefferson, and East Baton Rouge Parishes (Panel B). These three parishes had high population density before and after Katrina's landfall (Periods D and F). Orleans Parish and Jefferson Parish were closest to the storm track and had the highest number of people affected by the hurricane. 


\subsection{Identification of Critical Periods}

We identified six time periods of interest using loess-smoothing technique as shown in Table 1 and Figure 2 and examined the rates for each selected parish accordingly. The daily time series of daily CVD hospitalization rates per 10,000 elderly adults (shown as points) with the superimposed loess-smoothed curve (shown as line) are depicted in Figure 2 for Orleans Parish (Panel A), Jefferson Parish (Panel B), and East Baton Rouge Parish (Panel C), respectively. The landfall occurred on 29 August 2005 was indicated by a border between Periods T2 and T3, right after day 240. In Figure 2, the different hues and capital letters (T1-T6) indicate six distinct time periods according to Table 1.

In Figure 1 we mapped CVD counts and rates corresponding to the time periods before (Period T1, Panels C and D) and soon after the storm (Periods T3 and T4, Panels E and F). Prior to the storm the number of older residents in the East Baton Rouge Parish was comparable with the Orleans Parish. After the storm it received evacuees [29], including over five thousand older adults. Although St Bernard Parish also had a high rate of CVD, however due to a low population density the number of hospitalization records were insufficient for the further analysis.
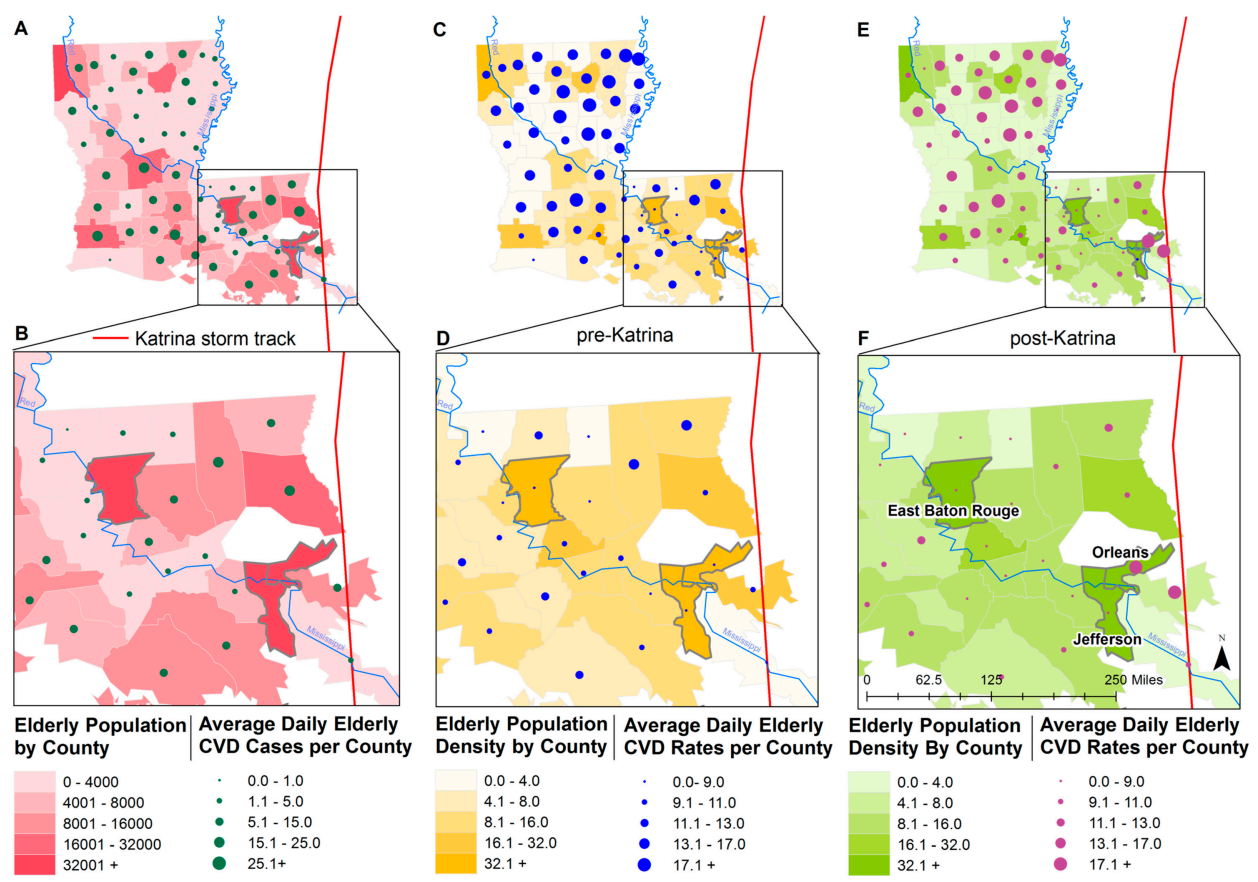

Figure 1. Geographic distribution of older population and average daily cardiovascular disease (CVD) cases per county shown for the state of Louisiana (Panel A) and a close-up showing Orleans, Jefferson, and East Baton Rouge Parishes (Panel B) for the whole study period (Periods T1-T6). Geographic distribution of population density (population $/ \mathrm{mi}^{2}$ ) and average daily CVD rates before the storm (Period T1) are shown for Louisiana (Panel C) and close-ups of three study parishes (Panel D), and after the storm (Periods T3 and T4), for Louisiana (Panel E) and a close-up of three study parishes (Panel F). 
Table 1. Six time periods (T1-T6) identified for in-depth evaluation.

\begin{tabular}{cccl}
\hline Period & Ending Point Knot & Duration (Days) & \multicolumn{1}{c}{ Description } \\
\hline T1 & $\begin{array}{c}\text { Day 225 } \\
\text { (13 August 2005) }\end{array}$ & 219 & $\begin{array}{l}\text { The pre-Katrina period, before the storm or major } \\
\text { warnings and evacuations. }\end{array}$ \\
\hline T2 & $\begin{array}{c}\text { Day 238 } \\
\text { (26 August 2005) }\end{array}$ & 13 & $\begin{array}{l}\text { The two weeks before Hurricane Katrina, when } \\
\text { officials began issuing warnings, and evacuations } \\
\text { began. }\end{array}$ \\
\hline T3 & $\begin{array}{c}\text { Day 247 } \\
\text { (4 September 2005) }\end{array}$ & 9 & $\begin{array}{l}\text { The week immediately following Hurricane Katrina, } \\
\text { starting the day before landfall, and ending at the } \\
\text { peak. }\end{array}$ \\
\hline T4 & $\begin{array}{c}\text { Day 275 } \\
\text { (2 October 2005) }\end{array}$ & 28 & $\begin{array}{l}\text { The first month following the immediate period. } \\
\text { T5 }\end{array} \quad \begin{array}{c}\text { Day 303 } \\
\text { (30 October 2005) }\end{array}$ \\
\hline T6 & $\begin{array}{c}\text { Day 710 } \\
\text { (17 December 2006) }\end{array}$ & 413 & The second months after the immediate period. \\
\hline
\end{tabular}

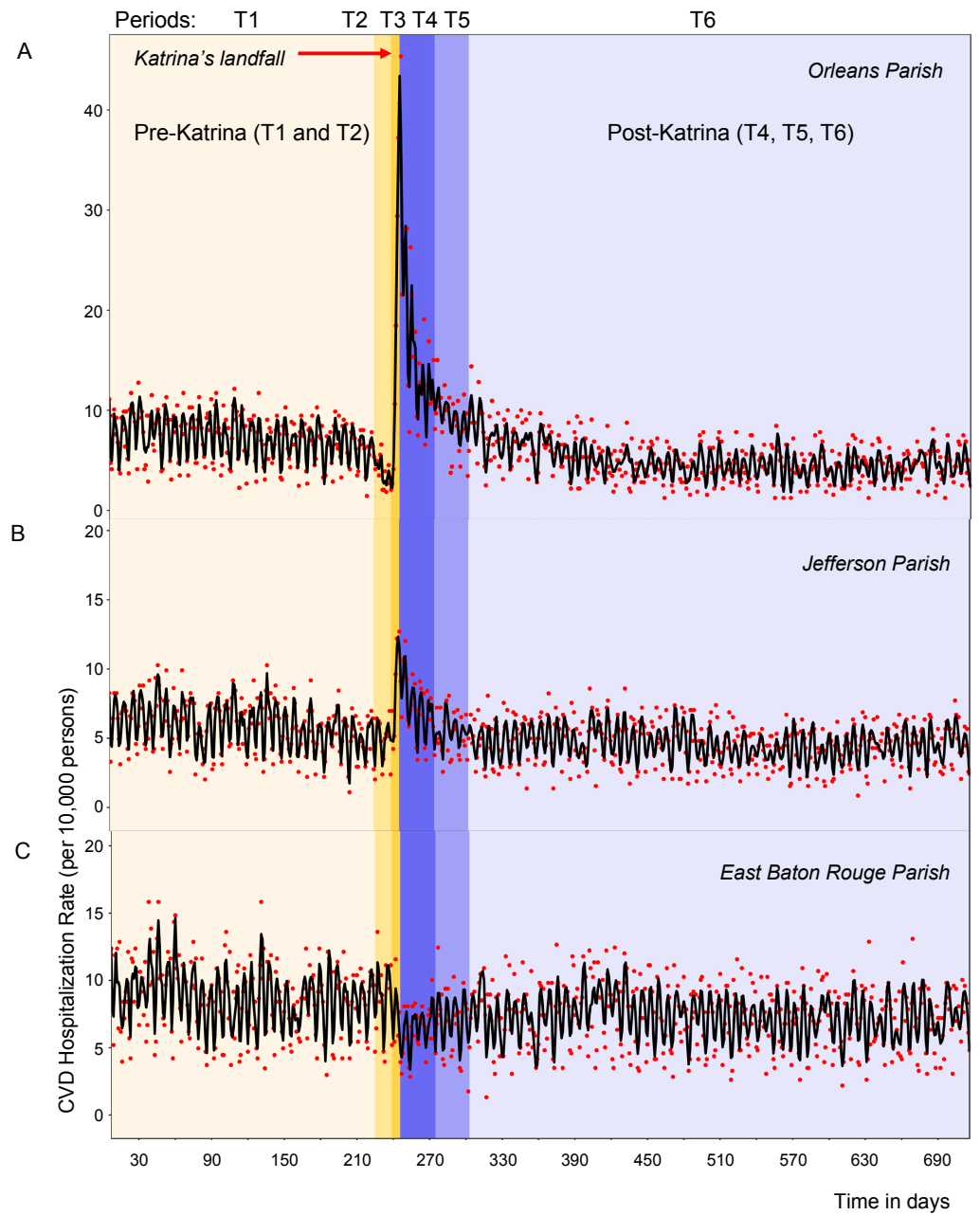

Figure 2. Time series of daily CVD hospitalization rates per 10,000 elderly adults with superimposed smoothed values for 7 January 2005-17 December 2006 in Orleans Parish (Panel A), Jefferson Parish (Panel B), and East Baton Rouge Parish (Panel C). Actual daily hospitalization rates are displayed as points; rates predicted by a loess-smoother are displayed as lines. The different hues and capital letters indicate six distinct time periods with landfall occurred on 29 August 2005 right after day 240, at the border between $\mathrm{T} 2$ and $\mathrm{T} 3$ periods. 
As shown in Table 2, Orleans Parish had a notably high average daily CVD hospitalization rate of $17.0 \pm 10.23$ cases/day per 10,000 people aged 65+ after the storm (Periods T3 and T4), while the number of residents declined by almost 17,000 people. In East Baton Rouge the total number of older adults increased by almost 5000 people, although with some decline in CVD rates.

Table 2. Demographic characteristics and cardiovascular disease (CVD) rates for three parishes of Louisiana for total, black and white older adults before (Period T1: 7 January-9 August 2005) and after (Periods T3 and T4: 27 August-2 October 2005) Hurricane Katrina.

\begin{tabular}{|c|c|c|c|c|c|c|c|c|c|}
\hline \multirow{2}{*}{\multicolumn{2}{|c|}{$\begin{array}{c}\text { Characteristics } \\
\text { Period }\end{array}$}} & \multicolumn{2}{|c|}{ Population Estimates (\%) } & \multicolumn{2}{|c|}{$\begin{array}{l}\text { Population Density } \\
\left.\text { (people/mi } / \mathrm{mi}^{2}\right)\end{array}$} & \multicolumn{2}{|c|}{$\begin{array}{c}\text { Average } \\
\text { Daily Cases }\end{array}$} & \multicolumn{2}{|c|}{$\begin{array}{c}\text { Average Dailyrates } \pm \text { st. } \\
\text { Deviation }\end{array}$} \\
\hline & & T1 & T3-T4 & T1 & T3-T4 & T1 & T3-T4 & T1 & T3-T4 \\
\hline \multirow[t]{2}{*}{ Orleans } & Black & $26,648(54.8 \%)$ & $15,105(47.6 \%)$ & 76.2 & 43.2 & 19.7 & 29.9 & $7.4 \pm 2.70$ & $19.8 \pm 13.70$ \\
\hline & White & $20,494(42.2 \%)$ & $16,126(50.4 \%)$ & 58.6 & 46.1 & 14.5 & 23.5 & $7.1 \pm 2.82$ & $14.5 \pm 7.79$ * \\
\hline Jefferson & Total & 54,513 & 58,256 & 111.7 & 119.4 & 32.3 & 43.5 & $5.9 \pm 1.90$ & $7.5 \pm 2.58$ \\
\hline \multirow{3}{*}{$\begin{array}{l}\text { East Baton } \\
\text { Rouge }\end{array}$} & Total & 40,425 & 45,837 & 85.9 & 97.4 & 35.3 & 29.7 & $8.7 \pm 2.74$ & $6.5 \pm 1.91$ \\
\hline & Black & $11,337(28.0 \%)$ & $13,436(29.3 \%)$ & 24.1 & 28.6 & 11.9 & 11.7 & $10.5 \pm 4.00$ & $8.7 \pm 3.68$ \\
\hline & White & $28,174(69.7 \%)$ & $31,398(68.5 \%)$ & 59.9 & 66.7 & 22.8 & 17.7 & $8.1 \pm 2.77^{* * *}$ & $5.6 \pm 1.91$ \\
\hline
\end{tabular}

\subsection{Segmented Regression Analysis}

The time series of daily rates with the superimposed fit from the segmented regression for each of six periods and for all three parishes are shown in Figure 3 (Panels A, B and C). As shown in Table 3, In Orleans Parish, the average CVD hospitalization rates was 7.25 cases/day per 10,000 persons and was decreasing slowly for over 6 months before Katrina (Period T1). During the evacuation week (Period T2), it dropped to 3.83 cases/day (Tukey-test, $p=0.002$, as compared to T1). In the week following Katrina (Period T3), the average daily rate increased drastically to $21.18(p<0.0001)$ by 3.12 additional cases per day.

The rate reached its peak of 45.36 cases/day on Sunday, 4 September, 6 days after Hurricane Katrina's landfall. In the following month (Period T4) the daily rate remained significantly high 15.52 cases / day $(p<0.0001)$ compared to pre-storm, pre-evacuation Period T1, but was decreasing by 3.56 cases per day. Two months after the landfall (Period T5) the average rate returned to a pre-storm, pre-evacuation level and then started to decline in Period T6 in manner similar to Period T1.

As shown in Table 3, in Jefferson Parish the hospitalization rate was increasing from an average rate of 5.01 cases/day during evacuation Period T2, one week before landfall, to 8.18 cases/day in a week after landfall ( $p<0.05$, compared to T1). The highest rate 12.7 cases/day was observed on Saturday 3 September, 5 days after Hurricane Katrina's landfall. The month following the peak, rates remained significantly high, at 7.26 cases $/$ day $(p=0.001)$. Two months after, average rate returned to 5.36 cases/day, similar to the pre-evacuation pre-storm Period T1 ( $p=0.9)$.

In contrast with Orleans, in East Baton Rouge Parish while the average hospitalization rates remained stable over all study periods except for a week after the landfall Period T3, when the rates were rapidly declining by 0.47 cases per day $(p<0.001)$. In the month following landfall, the average rate of 6.55 cases/day was a significantly lower as compared to 8.69 cases/day per 10,000 persons in Period T1 $(p=0.003)$. During the evacuation and after the landfall (Periods T2-T6), rates in East Baton Rouge Parish appeared to change in the opposite direction of Orleans Parish and Jefferson Parish. 


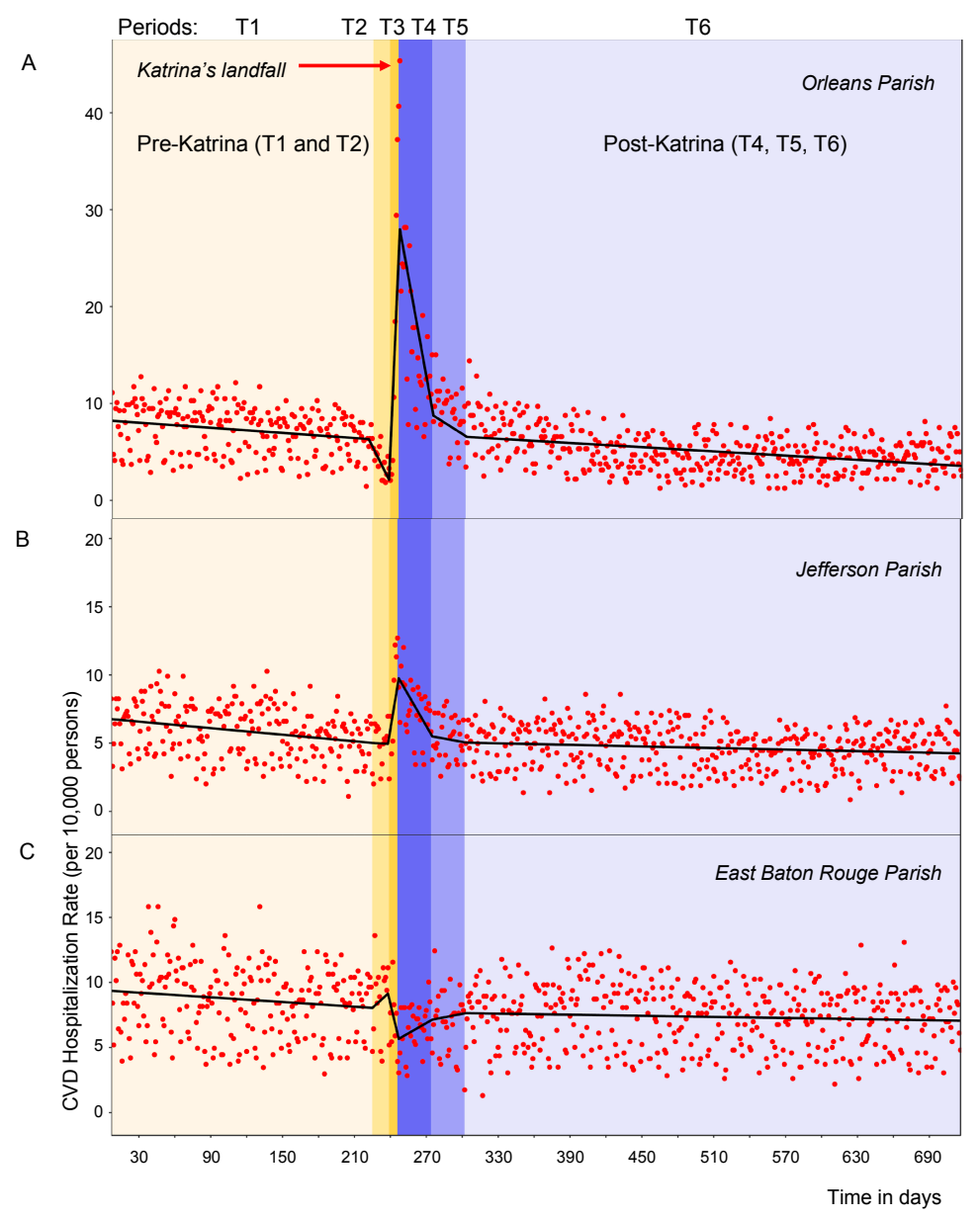

Figure 3. Time series of daily CVD hospitalization rates per 10,000 elderly adults with superimposed predicted values for 7 January 2005-17 December 2006 in Orleans Parish (Panel A), Jefferson Parish (Panel B), and East Baton Rouge Parish (Panel C). Actual daily hospitalization rates are displayed as points; rates predicted by a piecewise regression model are displayed as lines. The different hues and capital letters indicate the six distinct time periods with landfall occurred on 29 August 2005 right after day 240, at the border between T2 and T3 periods.

Table 3. Summary statistics for CVD hospitalization rates (daily cases per 10,000 older adults) before (Periods T1 and T2), during (Period T3), and after Hurricane Katrina (Periods T4, T5, and T6) in three parishes for total, black and white older adults. Slopes and intercepts were generated using segmented regression models.

\begin{tabular}{|c|c|c|c|c|c|c|c|}
\hline \multicolumn{2}{|c|}{ Periods } & T1 & $\mathrm{T} 2$ & T3 & T4 & T5 & T6 \\
\hline \multicolumn{2}{|c|}{ Number of days } & 219 & 13 & 9 & 28 & 28 & 413 \\
\hline \multicolumn{2}{|c|}{ Date Range } & $\begin{array}{c}\text { 7 January } \\
\text { 2005-13 August }\end{array}$ & 14-26 August & $\begin{array}{l}27 \text { August-4 } \\
\text { September }\end{array}$ & $\begin{array}{c}5 \\
\text { September-2 } \\
\text { October }\end{array}$ & $\begin{array}{c}\text { 3-30 } \\
\text { October }\end{array}$ & $\begin{array}{c}31 \text { October-17 } \\
\text { December } \\
2006\end{array}$ \\
\hline \multicolumn{8}{|c|}{ Total population } \\
\hline $\begin{array}{l}\text { Orleans } \\
\text { Parish }\end{array}$ & $\begin{array}{c}\text { Min, Max } \\
\text { Mean } \pm \text { SD } \\
\text { Intercept }{ }^{b} \\
\text { Slope } \pm \text { SE }\end{array}$ & $\begin{array}{c}1.44,12.76 \\
7.25 \pm 2.44 \\
8.31 \\
-0.01 \pm 0.003\end{array}$ & $\begin{array}{c}1.85,6.58 \\
3.91 \pm 1.45^{\mathrm{a}} \\
5.07 \\
-0.24 \pm 0.06^{\mathrm{c}}\end{array}$ & $\begin{array}{c}2.06,45.36 \\
18.46 \pm 17.3^{\mathrm{a}} \\
4.99 \\
3.12 \pm 0.19^{\mathrm{c}}\end{array}$ & $\begin{array}{c}6.5,28.15 \\
13.76 \pm 6.51^{a} \\
27.28 \\
-3.56 \pm 0.17^{c}\end{array}$ & $\begin{array}{c}3.4,15.02 \\
9.54 \pm 2.78 \\
8.66 \\
0.61 \pm 0.06^{\mathrm{c}}\end{array}$ & $\begin{array}{c}1.25,14.39 \\
4.69 \pm 2.08^{\mathrm{a}} \\
6.51 \\
0.07+0.03^{\mathrm{c}}\end{array}$ \\
\hline $\begin{array}{l}\text { Jefferson } \\
\text { Parish }\end{array}$ & $\begin{array}{c}\text { Min, Max } \\
\text { Mean } \pm \text { SD } \\
\text { Intercept } \\
\text { Slope } \pm \text { SE }\end{array}$ & $\begin{array}{c}1.10,10.27 \\
5.90 \pm 1.90 \\
6.82 \\
-0.01 \pm 0.002\end{array}$ & $\begin{array}{c}2.02,6.97 \\
5.01 \pm 1.52 \\
5.02 \\
0.003 \pm 0.05\end{array}$ & $\begin{array}{c}2.38,12.70 \\
8.18 \pm 3.70^{\mathrm{a}} \\
5.49 \\
0.54 \pm 0.14^{\mathrm{c}}\end{array}$ & $\begin{array}{c}3.43,12.02 \\
7.26 \pm 2.15^{\mathrm{a}} \\
9.60 \\
-0.68 \pm 0.11^{\mathrm{c}}\end{array}$ & $\begin{array}{c}2.57,8.07 \\
5.36 \pm 1.53 \\
5.48 \\
0.14 \pm 0.04^{\mathrm{c}}\end{array}$ & $\begin{array}{c}0.86,8.58 \\
4.65 \pm 1.57^{\mathrm{a}} \\
5.04 \\
0.01 \pm 0.02\end{array}$ \\
\hline $\begin{array}{c}\text { East BR } \\
\text { Parish }\end{array}$ & $\begin{array}{c}\text { Min, Max } \\
\text { Mean } \pm \text { SD } \\
\text { Intercept } \\
\text { Slope } \pm \text { SE }\end{array}$ & $\begin{array}{c}2.97,15.83 \\
8.69 \pm 2.74 \\
9.40 \\
-0.01 \pm 0.003\end{array}$ & $\begin{array}{c}3.96,13.61 \\
9.11 \pm 2.69 \\
6.43 \\
0.09 \pm 0.08\end{array}$ & $\begin{array}{c}3.05,11.56 \\
6.52 \pm 2.58 \\
5.19 \\
-0.47 \pm 0.21^{c}\end{array}$ & $\begin{array}{c}2.84,10.04 \\
6.55 \pm 1.70^{\mathrm{a}} \\
4.58 \\
0.44 \pm 0.17^{\mathrm{c}}\end{array}$ & $\begin{array}{c}1.75,12.44 \\
6.96 \pm 2.42^{\mathrm{a}} \\
6.76 \\
-0.03 \pm 0.06\end{array}$ & $\begin{array}{c}1.31,13.09 \\
7.39 \pm 2.37^{\mathrm{a}} \\
7.20 \\
-0.02 \pm 0.02\end{array}$ \\
\hline
\end{tabular}


Table 3. Cont.

\begin{tabular}{|c|c|c|c|c|c|c|c|}
\hline \multicolumn{2}{|c|}{ Periods } & T1 & T2 & T3 & T4 & T5 & T6 \\
\hline \multicolumn{2}{|c|}{ Number of days } & 219 & 13 & 9 & 28 & 28 & 413 \\
\hline \multicolumn{2}{|c|}{ Date Range } & $\begin{array}{c}7 \text { January } \\
\text { 2005-13 August }\end{array}$ & 14-26 August & $\begin{array}{l}27 \text { August-4 } \\
\text { September }\end{array}$ & $\begin{array}{c}5 \\
\text { September-2 } \\
\text { October }\end{array}$ & $\begin{array}{c}\text { 3-30 } \\
\text { October }\end{array}$ & $\begin{array}{c}31 \text { October-17 } \\
\text { December } \\
2006\end{array}$ \\
\hline \multicolumn{8}{|c|}{ Black population } \\
\hline $\begin{array}{l}\text { Orleans } \\
\text { Parish }\end{array}$ & $\begin{array}{c}\text { Min, Max } \\
\text { Mean } \pm \text { SD } \\
\text { Intercept } \\
\text { Slope } \pm \text { SE }\end{array}$ & $\begin{array}{c}1.50,13.51 \\
7.37 \pm 2.70 \\
8.50 \\
-0.01 \pm 0.004\end{array}$ & $\begin{array}{c}1.13,8.26 \\
3.91 \pm 2.12^{\mathrm{a}} \\
4.94 \\
-0.28 \pm 0.08^{\mathrm{c}}\end{array}$ & $\begin{array}{c}1.50,64.22 \\
26.29 \pm 23.7^{\mathrm{a}} \\
5.16 \\
3.96 \pm 0.25^{\mathrm{c}}\end{array}$ & $\begin{array}{c}7.94,32.44 \\
17.54 \pm 8.00^{\mathrm{a}} \\
33.60 \\
-4.60 \pm 0.22^{\mathrm{c}}\end{array}$ & $\begin{array}{c}1.99,15.23 \\
9.10 \pm 3.51 \\
8.37 \\
0.86 \pm 0.08^{c}\end{array}$ & $\begin{array}{c}0.66,17.87 \\
5.30 \pm 2.43^{\mathrm{a}} \\
6.40 \\
0.07 \pm 0.03^{\mathrm{c}}\end{array}$ \\
\hline $\begin{array}{l}\text { Jefferson } \\
\text { Parish }\end{array}$ & $\begin{array}{c}\text { Min, Max } \\
\text { Mean } \pm \text { SD } \\
\text { Intercept } \\
\text { Slope } \pm \text { SE }\end{array}$ & $\begin{array}{c}1.61,22.56 \\
6.76 \pm 3.94 \\
6.96 \\
-0.002 \pm 0.004\end{array}$ & $\begin{array}{c}1.61,16.11 \\
6.58 \pm 4.32 \\
6.43 \\
-0.03 \pm 0.08\end{array}$ & $\begin{array}{c}1.61,20.66 \\
11.79 \pm 6.81^{\mathrm{a}} \\
6.87 \\
0.77 \pm 0.25^{\mathrm{c}}\end{array}$ & $\begin{array}{c}2.95,16.23 \\
7.05 \pm 3.78 \\
12.46 \\
-1.09 \pm 0.22^{c}\end{array}$ & $\begin{array}{c}1.48,10.33 \\
4.86 \pm 2.31 \\
3.17 \\
0.45 \pm 0.08^{c}\end{array}$ & $\begin{array}{c}1.48,17.71 \\
5.81 \pm 2.95^{\mathrm{a}} \\
5.92 \\
-0.10 \pm 0.03^{\mathrm{c}}\end{array}$ \\
\hline $\begin{array}{l}\text { East BR } \\
\text { Parish }\end{array}$ & $\begin{array}{c}\text { Min, Max } \\
\text { Mean } \pm \text { SD } \\
\text { Intercept } \\
\text { Slope } \pm \text { SE }\end{array}$ & $\begin{array}{c}1.76,20.29 \\
10.48 \pm 4.00 \\
11.67 \\
-0.01 \pm 0.004\end{array}$ & $\begin{array}{c}5.29,18.52 \\
11.81 \pm 4.65 \\
10.14 \\
0.16 \pm 0.09\end{array}$ & $\begin{array}{c}2.23,13.40 \\
7.30 \pm 3.72 \\
11.36 \\
-0.70 \pm 0.27^{c}\end{array}$ & $\begin{array}{c}4.47,19.35 \\
9.22 \pm 3.60 \\
7.04 \\
0.68 \pm 0.25^{\mathrm{c}}\end{array}$ & $\begin{array}{c}0.74,20.10 \\
8.45 \pm 4.28 \\
10.24 \\
-0.16 \pm 0.09\end{array}$ & $\begin{array}{c}1.49,20.84 \\
8.90 \pm 3.55^{\mathrm{a}} \\
9.13 \\
0.04 \pm 0.04\end{array}$ \\
\hline \multicolumn{8}{|c|}{ White population } \\
\hline $\begin{array}{l}\text { Orleans } \\
\text { Parish }\end{array}$ & $\begin{array}{c}\text { Min, Max } \\
\text { Mean } \pm \text { SD } \\
\text { Intercept } \\
\text { Slope } \pm \text { SE }\end{array}$ & $\begin{array}{c}0.98,16.59 \\
7.09 \pm 2.83 \\
8.06 \\
-0.01 \pm 0.003\end{array}$ & $\begin{array}{c}1.95,5.86 \\
4.20 \pm 1.05^{\mathrm{a}} \\
5.29 \\
-0.18 \pm 0.06^{\mathrm{c}}\end{array}$ & $\begin{array}{c}2.44,30.39 \\
16.56 \pm 11.7^{\mathrm{a}} \\
5.17 \\
2.32 \pm 0.20^{\mathrm{c}}\end{array}$ & $\begin{array}{c}4.96,23.30 \\
13.80 \pm 6.15^{\mathrm{a}} \\
21.75 \\
-2.60 \pm 0.18^{\mathrm{c}}\end{array}$ & $\begin{array}{c}3.10,15.50 \\
8.81 \pm 2.89 \\
8.96 \\
0.39 \pm 0.06^{\mathrm{c}}\end{array}$ & $\begin{array}{c}0.62,13.64 \\
4.76 \pm 2.43^{\mathrm{a}} \\
6.66 \\
0.08 \pm 0.03^{\mathrm{c}}\end{array}$ \\
\hline $\begin{array}{l}\text { Jefferson } \\
\text { Parish }\end{array}$ & $\begin{array}{c}\text { Min, Max } \\
\text { Mean } \pm \text { SD } \\
\text { Intercept } \\
\text { Slope } \pm \text { SE }\end{array}$ & $\begin{array}{c}1.31,9.82 \\
5.90 \pm 1.90 \\
6.84 \\
-0.01 \pm 0.002\end{array}$ & $\begin{array}{c}1.96,6.76 \\
5.00 \pm 1.49 \\
4.99 \\
-0.0001 \pm \\
0.04\end{array}$ & $\begin{array}{c}2.62,12.56 \\
7.76 \pm 3.34^{\mathrm{a}} \\
5.40 \\
0.52 \pm 0.12^{\mathrm{c}}\end{array}$ & $\begin{array}{c}3.24,11.95 \\
7.43 \pm 2.21^{\mathrm{a}} \\
9.34 \\
-0.64 \pm 0.11^{\mathrm{c}}\end{array}$ & $\begin{array}{c}2.23,8.51 \\
5.47 \pm 1.72 \\
5.86 \\
0.10 \pm 0.04^{c}\end{array}$ & $\begin{array}{c}0.81,8.71 \\
4.55 \pm 1.58 \text { a } \\
4.99 \\
0.03 \pm 0.02\end{array}$ \\
\hline $\begin{array}{l}\text { East BR } \\
\text { Parish }\end{array}$ & $\begin{array}{c}\text { Min, Max } \\
\text { Mean } \pm \text { SD } \\
\text { Intercept } \\
\text { Slope } \pm \text { SE }\end{array}$ & $\begin{array}{c}2.48,15.97 \\
8.09 \pm 2.77 \\
8.57 \\
-0.004 \pm 0.003\end{array}$ & $\begin{array}{c}3.19,13.13 \\
8.16 \pm 2.73 \\
7.79 \\
0.03 \pm 0.06\end{array}$ & $\begin{array}{c}2.55,10.51 \\
6.17 \pm 2.63 \\
7.74 \\
-0.33 \pm 0.18\end{array}$ & $\begin{array}{c}1.91,8.60 \\
5.53 \pm 1.65^{\mathrm{a}} \\
5.25 \\
0.34 \pm 0.16^{\mathrm{c}}\end{array}$ & $\begin{array}{c}1.27,10.19 \\
6.34 \pm 2.26^{\mathrm{a}} \\
5.90 \\
0.02 \pm 0.06\end{array}$ & $\begin{array}{c}0.64,13.38 \\
6.83 \pm 2.40^{\mathrm{a}} \\
7.10 \\
-0.05 \pm 0.02\end{array}$ \\
\hline
\end{tabular}

\subsection{Racial Differences in CVD Rates}

When average hospitalization rates are calculated separately for black and white older adults for two main periods: pre-Katrina (Period T1) and during periods T3 and T4: starting the day after landfall and ending 28 days after the peak response (see Table 2), several differences are revealed. The proportion of black residents in Orleans Parish was higher than in Jefferson and East Baton Rouge Parish before and after the storm, yet the reduction in population in Orleans Parish was almost twice as large among black residents than white residents. In all parishes the racial differences in CVD rates were notable either before or after the storm (Tables 2 and 3, Figure 4). In Orleans Parish, the highest CVD rates, which stand out as outliers about a week after landfall, are all for black adults. They experienced a significant increase in rates soon after landfall of 26.3 and 17.5 cases/day in Periods $\mathrm{T} 3$ and T4, respectively $(p<0.001$, Table 3$)$. The direct comparison of average daily rates between black and white older adults post landfall (19.8 \pm 13.7 vs. $14.5 \pm 7.8, p<0.05$, Table 2$)$ shows significantly higher rates black patients. In Jefferson and East Baton Rouge Parish, the CVD rates were significantly higher in black than in white older adults before the storm. 


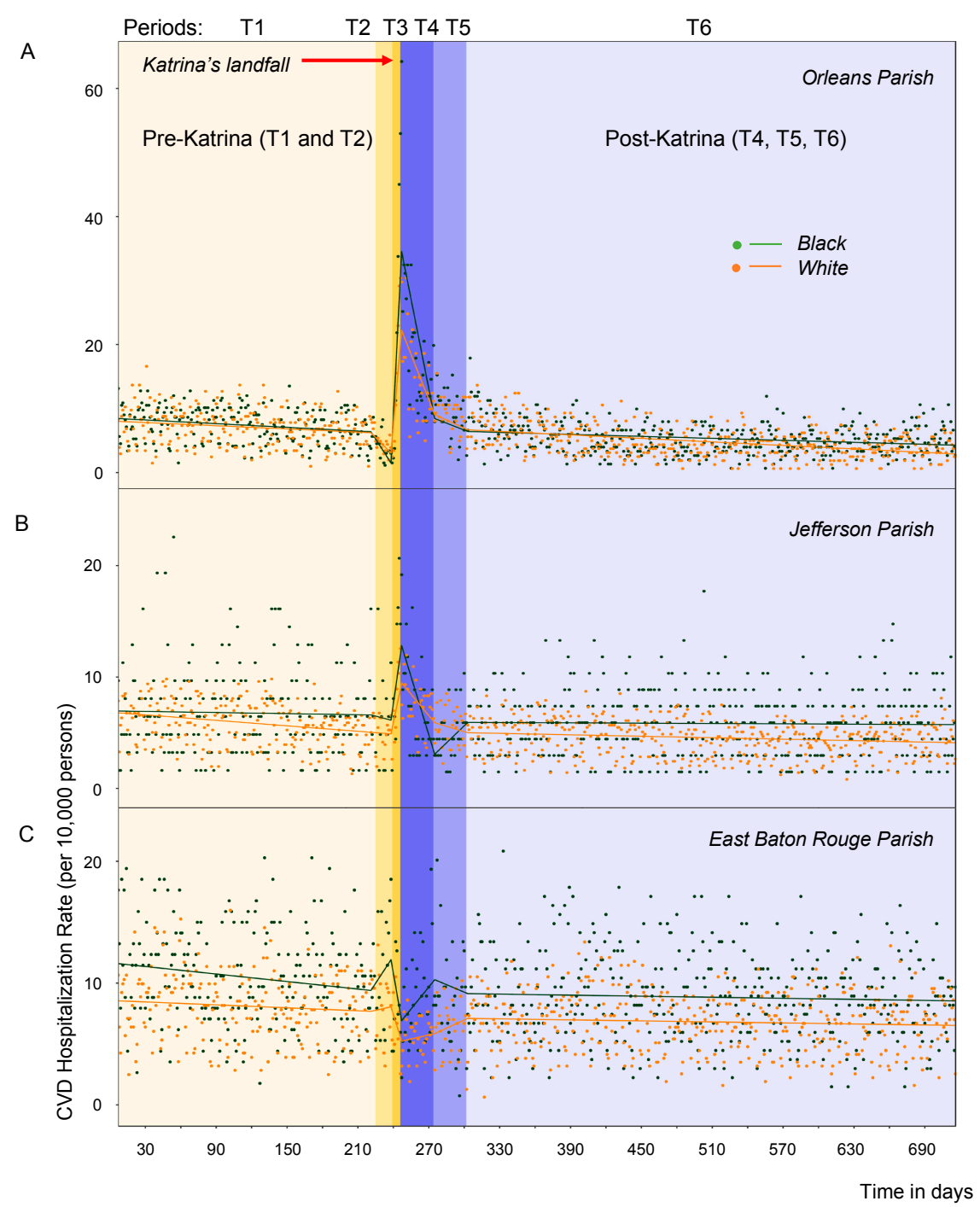

Figure 4. Time series of daily CVD hospitalization rates per 10,000 elderly adults with superimposed predicted values, grouped by race, for 7 January 2005-17 December 2006 in Orleans Parish (Panel A), Jefferson Parish (Panel B), and East Baton Rouge Parish (Panel C). Actual daily hospitalization rates are displayed as points; rates predicted using a piecewise regression model are displayed as lines: teal and orange lines indicate CVD rates for black and white older adults, respectively. The different hues and capital letters indicate the six distinct time periods with landfall occurred on 29 August 2005 right after day 240, at the border between T2 and T3 periods.

In the most affected Orleans Parish, white adults also experienced significant increases immediately after the storm reaching 16.6 and 13.8 cases/day in Periods T3 and T4, respectively $(p<0.02$, Table 3$)$ but of a lesser extent. The week following landfall, each day brought new hospitalizations: on average $3.96 \pm 0.25$ for blacks and $2.32 \pm 0.20$ for whites. During the post-Katrina period of stabilization and recovery in all parishes the average daily rates in both black and white adults were consistently lower than before the storm.

\section{Discussion}

Our study demonstrates significant changes in CVD hospitalization rates in Orleans Parish, both during and following Hurricane Katrina's landfall. On Friday, 26 August, two days before the landfall, the governor of Louisiana, Kathleen Blanco, declared a state of emergency [3]. On Saturday, 27 August, Orleans Parish, Jefferson Parish and St. Bernard Parish ordered voluntary evacuations, recommending 
that all residents evacuate, particularly those living in lower areas. Mandatory evacuation was issued the day before landfall, on Sunday, 28 August [3]. On Wednesday 31 August, two days after landfall, New Orleans mayor Ray Nagin estimates that 50,000 to 100,000 people remain in the city, which officials say is $80 \%$ flooded [31]. Our analysis demonstrated that during evacuation period the daily rates of CVD had significantly decreased in Orleans Parish. The rates then spiked immediately after Katrina's landfall in all older adults, especially in black residents. The rates appear to stabilize about two months after the landfall, coinciding with the clearing of floodwaters from New Orleans and the end of the emergency period, which lasted from the disaster event to the "dewatering" of New Orleans.

The surge in CVD observed in Louisiana after Hurricane Katrina could be due to many apparent reasons. Psychosocial stressors, lack of medication and proper support system are likely to play a key role. After Katrina, multiple reports have indicated high rates of psychosocial stress and post-traumatic stress, as well as an almost threefold increase in suicide rates [22]. Survivors had to cope with stressors such as searching for food and shelter, relocating, crowding, being in financial hardship, and dealing with insurance companies and social services [11]. These stressors not only reminded survivors of their trauma, but also introduced negative impacts to their capacity to cope [11]. This is a specific health concern given that psychological stress has emerged as a major risk factor for cardiovascular disease [36]. Stressors such as hurricanes and other natural disasters can cause chronic and acute mental stress, which can then trigger cardiovascular events [37]. After all, traditional cardiac risk factors only account for half of the causes of CVD, with most of the remaining risk explained by psychosocial factors [37].

There was also an estimated doubling of mental illness incidences following the storm: survivors who relocated to Oklahoma exhibited distress, disability, and post-traumatic stress disorders (PTSD) symptoms [38]. Survivors had an increased and abnormal baseline heart rate compared with that of controls, especially for those with depressions. Some survivors had decreased heart rate reactivity and heart rate variability, which are independent risk factors for cardiovascular disease [38]. In addition, an earlier study by the same group found immune system changes in a group of young, healthy Katrina survivors, stating that in the presence of PTSD, they had increased IL-6 levels, with unknown cardiovascular health complications [39]. In fact, heart conditions were reported to be one of the top three major causes of death among Louisiana victims [8].

Acute CVD events are known to be triggered by sudden emotional or physical stressors, such as unanticipated natural disasters, which are known for causing some of the strongest acute and subacute types of psychological stress [40]. It is likely to be the case for our study, when the majority of hospitalizations were due to acute conditions such as pericarditis, endocarditis, myocarditis, cardiomyopathy, cardiac dysrhythmias, and heart failure. The impact of psychosocial stress on cardiovascular health can be understood through the concept of allostasis-the ability to maintain stability through change, allowing one to respond to environmental demands, such as shifts in our physical state or dealing with stressful situations [40,41]. Both the sympathetic nervous system and hypothalamus-pituitary-adrenal (HPA) axis are involved in allostatic responses [40]. The adrenal medulla and sympathetic nerves release catecholamines when the sympathetic nervous system or HPA axis are activated, and the hypothalamus releases corticotrophin-releasing hormones that mediate the pituitary's release of corticotrophin, and thus, the adrenal cortex's release of cortisol [40]. Allostatic load then results from the allostatic mediator hormones changing cellular physiological and pathophysiological responses. Stress can trigger allostatic load, which can eventually, in turn, trigger cardiovascular disease [40]. It is very possible that Hurricane Katrina, which was both a sudden catastrophic event, and thus a source of both immediate and chronic stress, could have triggered allostatic load, which then led to the sharp increase in CVD rates observed after landfall, both immediately and even a month later.

It is worth noting that mortality rates for black adults was 1.7 to 4 times higher compared to rates for white adults in Orleans Parish [8]. Higher mortality rates were also seen for black adults 75 years and older compared to white adults of the same age group [8]. Low-income households, 
minority households, and households with elderly or disabled people are also less likely to evacuate than other households [42]. The already-existing gap in CVD rates between black and white older adults, has predisposed blacks to be more greatly impacted in the aftermath of the storm. It may appear that, perhaps the black adults were experiencing CVD sooner and at higher rates, that on average not as many survived, especially those prone to CVD; thus, rates of CVD deaths for the black population fell in the months after due to the loss of these individuals. Another possibility could be that access to healthcare and other resources differed significantly for these two racial groups following the storm, so black individuals were still experiencing CVD events, but were faced with limited hospital access [43]. Studies have indicated that black individuals have a higher likelihood of experiencing PTSD following a hurricane, compared to white individuals, and reported a greater impact of loss of services compared to white adults [43]. Yet another explanation could be that black residents lived in neighborhoods that were affected by the storm at a greater magnitude, and thus left and returned to Orleans at lower rates than the white population, especially soon after the storm. Damaged areas were also more likely to be comprised on households with low socioeconomic level. Both race and class are intertwined in this case as a part of the residential segregation reported in Orleans Parish, which results in polarized social capital for those groups as well as access to different institutions regarding emergency preparedness [7,44]. Stakeholders should take this into account and ensure access to medical care and emergency preparedness for all individuals, regardless of neighborhood, socioeconomic status, and race.

In East Baton Rouge Parish, CVD rates were higher on average for black adults, confirming what has been reported in literature previously [16,45,46]. East Baton Rouge Parish received evacuees [29], no significant changes in CVD hospitalization rates were noted, and the pattern was somewhat reversed to the observed in Orleans. This lack of detected change could exist for several reasons, including lack of tracking patient mobility and location of receiving care. First, in comparing rates across parishes, racial populations and time periods we rely on the population estimates that might be not accurate. Typically, the Intercensal estimates are updated yearly, and thus do not capture well fluctuations in population due to disaster related migrations, displacement, and losses. Furthermore, by focusing on the elderly population, which is already a subset of the evacuee population, we are not able to detect the impact on population younger than 65 years old, who yet could overwhelm health care facilities. There were not only people evacuating out of New Orleans, but also evacuees who returned eventually, as well as an influx of new people into the region due to construction jobs following the storm. From East Baton Rouge Parish, some evacuees also returned to Orleans Parish, especially due to its close proximity compared to other cities that accommodated many evacuees, such as Atlanta or Dallas.

We merged population data from American Community Survey estimates and Intercensal estimates to supplement the census data and account for a mass exodus from affected area; however, it would be more assuring to have reliable public resources to properly account for changes in population following disaster. Such data repositories should serve many purposes, including disaster mitigation and relieve and assessing the quality and efficiency in controlling the impact of a disaster. The study conducted by the Centers for Disease Control and Prevention soon after Hurricane Katrina revealed that chronic disease and related conditions, including cardiovascular and cerebrovascular diseases accounted for a significant proportion of visits to emergency treatment facilities in and around New Orleans, particularly among people ages 60 years or older [47]. This study led us to think about importance of better harmonization of all available data, including hospitalization claims and surveillance records [48].

This study used patient's county of residence for billing purposed and is unlikely to track well where patients received their care. This phenomenon was observed in studying hospitalizations due to seasonal pneumonia and influenza using CMS claims [49]. We had utilized the information contained in the CMS records represents that of the beneficiary residency, and not the provider. Survivors from Orleans Parish or Jefferson Parish may have received care in East Baton Rouge Parish, but this type 
of information is not readily available. Due to lack of knowledge how reliably a patient's residential address, recorded by the CMS database, reflect the actual patient location, we roughly assessed hospital utilization. We estimated that before the Katrina's landfall $97 \%$ of Orleans Parish patients were treated in Louisiana; during and two months after the landfall, 45-56\% received health in hospitals outside of Louisiana; and afterwards $78 \%$ of patients with Orleans Parish county code of residence were treated in Louisiana. The access and utilization of healthcare facilities could have changed during disasters and we were not able to account for such changes. This crucial information is often scattered among various agencies and not readily available.

This report is one of the few papers discussing the impact of hurricanes on CVD hospitalization rates, as well as the disparities in rates between white and black elderly adults. We offered a novel application of segmented regression model to explore in detail a complex dynamic process with rapid rise and fall in CVD hospitalizations. Further research is recommended to identify patterns in CVD hospitalizations by subtype, as well as any differences in peak intensity between subtypes. We used Medicare records, which provide a broad coverage for the majority of American adults 65 years and older. While this data set is uniquely useful, it could not be used to provide timely reports during and after emergency, as it requires at least 6 months to request and assemble the records. It is expensive to operate and maintain even for experienced researchers. Yet, hurricanes are striking seasonally on a regular basis, so a solution for timely and reliable reporting is critical to develop proper preparedness strategies for hurricanes, whose impacts are consistently intensifying in the region. The presented findings provide the basis for planning resource allocation, among other disaster needs.

There are many questions we were still unable to address: What were the mechanisms underlying the disparities? Why did we see the disparities? What other forms of disparity occurred beyond race? After the event, did the disparity go away? Did the recovery for each group occur with the same speed or did difference occur in recovery by racial groups? Studies suggest that preparedness of black elders was not significantly different from that of whites; however, older black adults in lower income status were significantly less prepared for disaster than other groups [14]. This study only examined records 16 months post-Katrina, however the recovery from economic, physical and psychological damages may last for many years. The impact caused by hurricane damage, loss, or stress can be alleviated by housing, finance, and stress management. Studies of Kobe earthquake survivors show that "through event evaluation, social ties and community rebuilding efforts directly or indirectly facilitated the reframing of earthquake experiences into positive narratives" [50]. The reasons for the steady decline in CVD rates post-Katrina remain unclear; it might be due to older adults who were frail moved to other counties or states. We recommend that policies and programs for post-disaster evaluation should also consider the factors of family- and community-level enrichment, empowerment, and commemoration, allowing for the transcending and effective communication of the experience, ultimately leading to lasting improvements. Recovery periods could create opportunities for rebuilding infrastructure and reframing the social relationships, with proper policies and procedures these periods can serve as an optimal juncture to reduce racial, economic and environmental inequalities.

\section{Conclusions}

This study analyzed changes in elderly CVD hospitalization rates occurring during various time periods before, during, and after Hurricane Katrina in Orleans, East Baton Rouge, and Jefferson parishes, all of which are located near the storm's track. CVD hospitalization rates rose immediately after landfall in both Orleans and Jefferson parishes. This increase in CVD hospitalization rates was prolonged, lasting more than a month after landfall. An increase in CVD rates was higher among elderly black populations compared to elderly white populations in the weeks after landfall, indicating differences in level of impact in these two communities. The 2017-2018 hurricane seasons were particularly devastating, as storms like Harvey, Irma, Maria, and Jose ravaged major metropolitan hubs in Houston, Puerto Rico, and Dominica and prolong disasters of Florence and Michael in Carolinas 
and Florida. Considering the staggering economic and health impacts of such disasters, lessons from the past hurricanes, including Katrina experience should inform future health management decisions.

Author Contributions: Conceptualization, E.N.N. and K.K.H.C.; Methodology, E.N.N.; Software, N.A.B.; Validation, G.S., K.K.H.C. and E.N.N.; Formal Analysis, N.A.B.; Investigation, K.K.H.C.; Resources, E.N.N.; Data Curation, N.A.B.; Writing-Original Draft Preparation, N.A.B. and E.N.N.; Writing-Review \& Editing, E.N.N., G.S., and K.K.H.C.; Visualization, N.A.B. and E.N.N.; Supervision, E.N.N.; Project Administration and IRB Approval, E.N.N.; Funding Acquisition, E.N.N.

Funding: First author: N.A.B., received support for data analysis and manuscript preparation from the Tufts Post-Baccalaureate Research Program (PREP) grant funded by the NIH R25 GM066567. The use of Centers for Medicare and Medicaid Services hospitalization records for this study was enabled by the National Institutes of Health Grants R01-ES013171, U19-AI062627, and NO1-A150032. E.N.N. was also supported by the grant on "Ethical Dimensions of Data Access, Sharing, and Communication" from the Jonathan M. Tisch College of Civic Life at Tufts University.

Acknowledgments: Authors are thankful to Norbert Wilson, Tisch College faculty members, and referees for offering useful comments and to Steve Walker, from the Mississippi Automated Resource Information System for helping with mapping the storm track.

Conflicts of Interest: The authors declare no conflict of interest. The funders had no role in the design of the study; in the collection, analyses, or interpretation of data; in the writing of the manuscript, and in the decision to publish the results.

\section{Appendix A}

Table A1. Distribution of all records abstracted for the state of Louisiana from 7 January 2005 to 17 December 2006 by International Classification of Diseases (ICD) code and race.

\begin{tabular}{clcccccc}
\hline \multirow{2}{*}{$\begin{array}{c}\text { ICD-9M } \\
\text { Code }\end{array}$} & \multicolumn{1}{c}{ Description } & \multicolumn{2}{c}{ All Patients } & \multicolumn{2}{c}{ Black } & \multicolumn{2}{c}{ White } \\
\cline { 2 - 7 } & & Counts & $\%$ & Counts & $\%$ & Counts & $\%$ \\
\hline $390-398$ & $\begin{array}{l}\text { Acute/Chronic Rheumatic } \\
\text { Heart Disease }\end{array}$ & 1208 & $1.0 \%$ & 298 & $1.0 \%$ & 910 & $1.0 \%$ \\
\hline $401-405$ & Hypertensive Heart Disease & 7142 & $6.0 \%$ & 2869 & $9.8 \%$ & 4273 & $4.7 \%$ \\
\hline $410-414$ & Ischemic Heart Disease & 28,110 & $23.5 \%$ & 4763 & $16.2 \%$ & 23,347 & $25.9 \%$ \\
\hline $420-429$ & Other Heart Diseases & 47,503 & $39.7 \%$ & 11,248 & $38.2 \%$ & 36,255 & $40.2 \%$ \\
\hline $430-438$ & Cerebrovascular Disease & 23,309 & $19.5 \%$ & 6640 & $22.6 \%$ & 16,669 & $18.5 \%$ \\
\hline $440-449$ & $\begin{array}{l}\text { Diseases of arteries, } \\
\text { arterioles, and capillaries }\end{array}$ & 7070 & $5.9 \%$ & 2217 & $7.5 \%$ & 4853 & $5.4 \%$ \\
\hline $451-459$ & $\begin{array}{l}\text { Other diseases of the } \\
\text { circulatory system }\end{array}$ & 5270 & $4.4 \%$ & 1386 & $4.7 \%$ & 3884 & $4.3 \%$ \\
\hline Total & & 119,612 & & 29,421 & & 90,191 & \\
\hline
\end{tabular}


Table A2. The time series of daily cases and rates along with six time periods for the study population (example of the first 10 rows); full data set is available on request.

\begin{tabular}{|c|c|c|c|c|c|c|c|c|c|c|c|c|c|c|c|c|c|c|c|}
\hline & \multirow[t]{2}{*}{ Date } & \multirow[t]{2}{*}{ Day } & \multirow[t]{2}{*}{ Week } & \multirow[t]{2}{*}{ Period } & \multicolumn{6}{|c|}{ Periods (T1-T6) } & \multicolumn{3}{|c|}{ Orleans Parish } & \multicolumn{3}{|c|}{ Jefferson Parish } & \multicolumn{3}{|c|}{$\begin{array}{c}\text { East Baton Rouge } \\
\text { Parish }\end{array}$} \\
\hline & & & & & 1 & 2 & 3 & 4 & 5 & 6 & Count & Rate & Fitted & Count & Rate & Fitted & Count & Rate & Fitted \\
\hline 1 & 7 January 2005 & 7 & 1 & $\mathrm{~T} 1$ & 7 & 0 & 0 & 0 & 0 & 0 & 54 & 11.11 & 8.24 & 45 & 8.25 & 6.77 & 50 & 12.37 & 9.36 \\
\hline 2 & 8 January 2005 & 8 & 1 & $\mathrm{~T} 1$ & 8 & 0 & 0 & 0 & 0 & 0 & 23 & 4.73 & 8.23 & 18 & 3.30 & 6.76 & 34 & 8.41 & 9.35 \\
\hline 3 & 9 January 2005 & 9 & 2 & $\mathrm{~T} 1$ & 9 & 0 & 0 & 0 & 0 & 0 & 20 & 4.12 & 8.23 & 27 & 4.95 & 6.75 & 21 & 5.19 & 9.34 \\
\hline 4 & 10 January 2005 & 10 & 2 & $\mathrm{~T} 1$ & 10 & 0 & 0 & 0 & 0 & 0 & 46 & 9.47 & 8.22 & 35 & 6.42 & 6.74 & 48 & 11.87 & 9.34 \\
\hline 5 & 11 January 2005 & 11 & 2 & $\mathrm{~T} 1$ & 11 & 0 & 0 & 0 & 0 & 0 & 49 & 10.08 & 8.21 & 45 & 8.25 & 6.73 & 41 & 10.14 & 9.33 \\
\hline 6 & 12 January 2005 & 12 & 2 & $\mathrm{~T} 1$ & 12 & 0 & 0 & 0 & 0 & 0 & 37 & 7.61 & 8.20 & 41 & 7.52 & 6.73 & 50 & 12.37 & 9.33 \\
\hline 7 & 13 January 2005 & 13 & 2 & $\mathrm{~T} 1$ & 13 & 0 & 0 & 0 & 0 & 0 & 45 & 9.26 & 8.19 & 45 & 8.25 & 6.72 & 26 & 6.43 & 9.32 \\
\hline 8 & 14 January 2005 & 14 & 2 & $\mathrm{~T} 1$ & 14 & 0 & 0 & 0 & 0 & 0 & 33 & 6.79 & 8.18 & 35 & 6.42 & 6.71 & 52 & 12.86 & 9.31 \\
\hline 9 & 15 January 2005 & 15 & 2 & $\mathrm{~T} 1$ & 15 & 0 & 0 & 0 & 0 & 0 & 20 & 4.12 & 8.17 & 27 & 4.95 & 6.70 & 25 & 6.18 & 9.31 \\
\hline 10 & 16 January 2005 & 16 & 3 & $\mathrm{~T} 1$ & 16 & 0 & 0 & 0 & 0 & 0 & 18 & 3.70 & 8.16 & 17 & 3.12 & 6.69 & 16 & 3.96 & 9.30 \\
\hline
\end{tabular}


Table A3. Population, number of CVD cases and average daily rate of hospitalizations per 10,000 older adults before (Period T1: 7 January-9 August 2005) and after (Periods T3 and T4: 27 August-2 October 2005) in Louisiana.

\begin{tabular}{|c|c|c|c|c|c|c|c|}
\hline \multirow[b]{2}{*}{ FIPS Code } & \multirow[b]{2}{*}{ County } & \multicolumn{3}{|c|}{ Period T1 } & \multicolumn{3}{|c|}{ Period T3-T4 } \\
\hline & & Population & $\begin{array}{l}\text { Number } \\
\text { of Cases }\end{array}$ & $\begin{array}{c}\text { Average } \\
\text { Daily Rate }\end{array}$ & Population & $\begin{array}{l}\text { Number } \\
\text { of Cases }\end{array}$ & $\begin{array}{c}\text { Average } \\
\text { Daily Rate }\end{array}$ \\
\hline 22051 & Jefferson Parish, LA & 56,402 & 7331 & 5.7 & 56,019 & 1522 & 7.76 \\
\hline 22071 & Orleans Parish, LA & 54,628 & 8013 & 6.43 & 27,698 & 1880 & 19.39 \\
\hline 22033 & East Baton Rouge Parish, LA & 42,791 & 8056 & 8.26 & 45,236 & 1067 & 6.74 \\
\hline 22017 & Caddo Parish, LA & 33,775 & 9239 & 12 & 33,830 & 1251 & 10.57 \\
\hline 22103 & St. Tammany Parish, LA & 22,973 & 4948 & 9.45 & 25,498 & 838 & 9.39 \\
\hline 22019 & Calcasieu Parish, LA & 22,696 & 5497 & 10.62 & 22,623 & 889 & 11.23 \\
\hline 22055 & Lafayette Parish, LA & 19,973 & 4947 & 10.86 & 21,035 & 693 & 9.41 \\
\hline 22073 & Ouachita Parish, LA & 17,807 & 5772 & 14.22 & 18,065 & 798 & 12.62 \\
\hline 22079 & Rapides Parish, LA & 16,700 & 4700 & 12.34 & 16,979 & 609 & 10.25 \\
\hline 22015 & Bossier Parish, LA & 12,035 & 3022 & 11.01 & 12,695 & 397 & 8.93 \\
\hline 22109 & Terrebonne Parish, LA & 11,355 & 2917 & 11.27 & 11,756 & 376 & 9.14 \\
\hline 22105 & Tangipahoa Parish, LA & 11,292 & 3432 & 13.33 & 12,385 & 467 & 10.77 \\
\hline 22097 & St. Landry Parish, LA & 11,262 & 3420 & 13.32 & 11,573 & 419 & 10.34 \\
\hline 22057 & Lafourche Parish, LA & 10,822 & 2550 & 10.33 & 11,169 & 356 & 9.11 \\
\hline 22063 & Livingston Parish, LA & 9578 & 1771 & 8.11 & 10,665 & 215 & 5.76 \\
\hline 22087 & St. Bernard Parish, LA & 8931 & 2089 & 10.26 & 2632 & 303 & 32.89 \\
\hline 22045 & Iberia Parish, LA & 8534 & 2094 & 10.76 & 8703 & 276 & 9.06 \\
\hline 22113 & Vermilion Parish, LA & 7384 & 1968 & 11.69 & 7365 & 274 & 10.63 \\
\hline 22001 & Acadia Parish, LA & 7346 & 1855 & 11.08 & 7512 & 260 & 9.89 \\
\hline 22005 & Ascension Parish, LA & 6991 & 1465 & 9.19 & 8038 & 164 & 5.83 \\
\hline 22119 & Webster Parish, LA & 6786 & 2441 & 15.78 & 6817 & 315 & 13.2 \\
\hline 22101 & St. Mary Parish, LA & 6479 & 1566 & 10.6 & 6677 & 234 & 10.01 \\
\hline 22117 & Washington Parish, LA & 6309 & 2336 & 16.24 & 6388 & 283 & 12.66 \\
\hline 22009 & Avoyelles Parish, LA & 5641 & 1849 & 14.38 & 5910 & 263 & 12.71 \\
\hline 22099 & St. Martin Parish, LA & 5310 & 1413 & 11.67 & 5552 & 196 & 10.09 \\
\hline 22061 & Lincoln Parish, LA & 4983 & 1579 & 13.9 & 5017 & 197 & 11.22 \\
\hline 22069 & Natchitoches Parish, LA & 4829 & 1475 & 13.4 & 4873 & 206 & 12.08 \\
\hline 22089 & St. Charles Parish, LA & 4685 & 804 & 7.53 & 5006 & 125 & 7.13 \\
\hline 22039 & Evangeline Parish, LA & 4465 & 2048 & 20.12 & 4542 & 308 & 19.37 \\
\hline 22067 & Morehouse Parish, LA & 4458 & 1444 & 14.21 & 4390 & 226 & 14.71 \\
\hline 22115 & Vernon Parish, LA & 4448 & 1557 & 15.35 & 4487 & 253 & 16.11 \\
\hline 22053 & Jefferson Davis Parish, LA & 4414 & 1447 & 14.38 & 4493 & 207 & 13.16 \\
\hline 22011 & Beauregard Parish, LA & 4121 & 1244 & 13.24 & 4206 & 184 & 12.5 \\
\hline 22085 & Sabine Parish, LA & 3847 & 1062 & 12.11 & 3952 & 134 & 9.69 \\
\hline 22095 & St. John the Baptist Parish, LA & 3803 & 892 & 10.29 & 4293 & 116 & 7.72 \\
\hline 22047 & Iberville Parish, LA & 3615 & 799 & 9.69 & 3779 & 148 & 11.19 \\
\hline 22031 & De Soto Parish, LA & 3613 & 1195 & 14.51 & 3655 & 179 & 13.99 \\
\hline 22111 & Union Parish, LA & 3462 & 1224 & 15.51 & 3578 & 172 & 13.73 \\
\hline 22041 & Franklin Parish, LA & 3271 & 1230 & 16.49 & 3317 & 156 & 13.44 \\
\hline 22077 & Pointe Coupee Parish, LA & 3220 & 709 & 9.66 & 3443 & 98 & 8.13 \\
\hline 22003 & Allen Parish, LA & 3076 & 1076 & 15.34 & 3125 & 168 & 15.36 \\
\hline 22029 & Concordia Parish, LA & 2980 & 977 & 14.38 & 2986 & 120 & 11.48 \\
\hline 22083 & Richland Parish, LA & 2955 & 1280 & 19 & 2927 & 168 & 16.4 \\
\hline
\end{tabular}


Table A3. Cont.

\begin{tabular}{|c|c|c|c|c|c|c|c|}
\hline \multirow[b]{2}{*}{ FIPS Code } & \multirow[b]{2}{*}{ County } & \multicolumn{3}{|c|}{ Period T1 } & \multicolumn{3}{|c|}{ Period T3-T4 } \\
\hline & & Population & $\begin{array}{l}\text { Number } \\
\text { of Cases }\end{array}$ & $\begin{array}{c}\text { Average } \\
\text { Daily Rate }\end{array}$ & Population & $\begin{array}{l}\text { Number } \\
\text { of Cases }\end{array}$ & $\begin{array}{c}\text { Average } \\
\text { Daily Rate }\end{array}$ \\
\hline 22007 & Assumption Parish, LA & 2808 & 746 & 11.65 & 2937 & 77 & 7.49 \\
\hline 22027 & Claiborne Parish, LA & 2735 & 844 & 13.53 & 2740 & 108 & 11.26 \\
\hline 22093 & St. James Parish, LA & 2598 & 574 & 9.69 & 2741 & 68 & 7.09 \\
\hline 22049 & Jackson Parish, LA & 2510 & 1069 & 18.68 & 2540 & 157 & 17.66 \\
\hline 22043 & Grant Parish, LA & 2415 & 642 & 11.66 & 2470 & 86 & 9.95 \\
\hline 22037 & East Feliciana Parish, LA & 2318 & 662 & 12.53 & 2416 & 62 & 7.33 \\
\hline 22123 & West Carroll Parish, LA & 1934 & 914 & 20.73 & 1902 & 133 & 19.98 \\
\hline 22025 & Catahoula Parish, LA & 1496 & 536 & 15.71 & 1546 & 61 & 11.27 \\
\hline 22021 & Caldwell Parish, LA & 1462 & 769 & 23.07 & 1483 & 110 & 21.19 \\
\hline 22065 & Madison Parish, LA & 1424 & 508 & 15.65 & 1431 & 73 & 14.58 \\
\hline 22081 & Red River Parish, LA & 1346 & 445 & 14.5 & 1351 & 70 & 14.8 \\
\hline 22091 & St. Helena Parish, LA & 1324 & 250 & 8.28 & 1465 & 30 & 5.85 \\
\hline 22125 & West Feliciana Parish, LA & 1248 & 222 & 7.8 & 1393 & 32 & 6.56 \\
\hline 22023 & Cameron Parish, LA & 1229 & 176 & 6.28 & 910 & 34 & 10.68 \\
\hline
\end{tabular}

FIPS: Federal Information Processing Standards. 
Table A4. Summary statistics for CVD hospitalization rates (daily cases per 10,000 older adults) before (Periods T1 and T2), during (Period T3), and after Hurricane Katrina (Periods T4-T6) in three parishes for total, black and white older adults. Slopes and intercepts were generated using segmented regression models.

\begin{tabular}{|c|c|c|c|c|c|c|c|c|c|c|c|c|c|c|c|c|}
\hline \multicolumn{17}{|c|}{ Periods } \\
\hline & & \multicolumn{3}{|c|}{ T1-T2 } & \multicolumn{3}{|c|}{$\mathrm{T} 2-\mathrm{T} 3$} & \multicolumn{3}{|c|}{ T3-T4 } & \multicolumn{3}{|c|}{ T4-T5 } & \multicolumn{3}{|c|}{ T5-T6 } \\
\hline & & Intercept & $\begin{array}{l}\text { Slope } \\
\text { of T1 }\end{array}$ & $\begin{array}{l}\text { Slope } \\
\text { of T2 }\end{array}$ & Intercept & $\begin{array}{l}\text { Slope } \\
\text { of T2 }\end{array}$ & $\begin{array}{l}\text { Slope } \\
\text { of T3 }\end{array}$ & Intercept & $\begin{array}{l}\text { Slope } \\
\text { of T3 }\end{array}$ & $\begin{array}{l}\text { Slope } \\
\text { of T4 }\end{array}$ & Intercept & $\begin{array}{l}\text { Slope } \\
\text { of T4 }\end{array}$ & $\begin{array}{l}\text { Slope } \\
\text { of T5 }\end{array}$ & Intercept & $\begin{array}{l}\text { Slope } \\
\text { of T5 }\end{array}$ & $\begin{array}{l}\text { Slope } \\
\text { of T6 }\end{array}$ \\
\hline \multicolumn{17}{|c|}{ Total population } \\
\hline \multirow{3}{*}{ Orleans } & Estimate & 6.17 & -0.01 & -0.29 & -1.46 & -0.68 & 4.88 & 29.41 & 3.28 & -0.85 & 10 & -0.43 & -0.1 & 6.41 & -0.18 & -0.01 \\
\hline & St. Error & 0.31 & 0.002 & 0.09 & 1.75 & 0.26 & 0.37 & 2.39 & 0.66 & 0.15 & 1.08 & 0.08 & 0.07 & 0.19 & 0.03 & 0.001 \\
\hline & $\mathrm{R}^{2}$ & & 0.15 & & & 0.92 & & & 0.52 & & & 0.56 & & & 0.3 & \\
\hline \multirow{3}{*}{ Jefferson } & Estimate & 5.01 & -0.008 & 0.02 & 4.58 & -0.03 & 0.8 & 9.93 & 0.63 & -0.17 & 5.71 & -0.11 & -0.02 & 5.04 & -0.02 & -0.002 \\
\hline & St. Error & 0.24 & 0.002 & 0.07 & 0.84 & 0.13 & 0.18 & 0.72 & 0.2 & 0.05 & 0.47 & 0.03 & 0.03 & 0.15 & 0.02 & 0.001 \\
\hline & $\mathrm{R}^{2}$ & 0.07 & & & 0.61 & & & 0.31 & & & 0.31 & & & 0.03 & & \\
\hline East & Estimate & 8.03 & -0.01 & 0.13 & 9.06 & 0.01 & -0.48 & 5.86 & -0.22 & 0.04 & 7.44 & 0.06 & -0.04 & 7.65 & 0.02 & -0.001 \\
\hline Baton & St. Error & 0.36 & 0.003 & 0.1 & 1.13 & 0.17 & 0.24 & 0.63 & 0.17 & 0.04 & 0.56 & 0.04 & 0.04 & 0.23 & 0.03 & 0.001 \\
\hline Rouge & $\mathrm{R}^{2}$ & & 0.02 & & & 0.24 & & & 0.05 & & & 0.04 & & & 0.005 & \\
\hline \multicolumn{17}{|c|}{ Black population } \\
\hline \multirow{3}{*}{ Orleans } & Estimate & 6.22 & -0.01 & -0.32 & -3.97 & -1.09 & 6.56 & 36.61 & 4.31 & -1.16 & 10.35 & -0.57 & -0.12 & 6.25 & -0.21 & -0.005 \\
\hline & St. Error & 0.34 & 0.003 & 0.11 & 2.66 & 0.44 & 0.56 & 3.17 & 0.88 & 0.2 & 1.28 & 0.09 & 0.09 & 0.23 & 0.03 & 0.001 \\
\hline & $\mathrm{R}^{2}$ & & 0.13 & & & 0.91 & & & 0.53 & & & 0.61 & & & 0.19 & \\
\hline \multirow{3}{*}{ Jefferson } & Estimate & 6.57 & -0.002 & -0.008 & 4.41 & -0.29 & 1.62 & 13.21 & 0.89 & -0.39 & 3.61 & -0.25 & 0.1 & 5.9 & 0.09 & -0.0004 \\
\hline & St. Error & 0.53 & 0.004 & 0.17 & 1.86 & 0.31 & 0.39 & 1.39 & 0.38 & 0.09 & 0.77 & 0.06 & 0.05 & 0.28 & 0.04 & 0.001 \\
\hline & $\mathrm{R}^{2}$ & & 0.001 & & & 0.54 & & & 0.36 & & & 0.3 & & & 0.01 & \\
\hline East & Estimate & 9.31 & -0.01 & 0.4 & 12.63 & 0.25 & -0.87 & 7.07 & -0.08 & 0.15 & 10.89 & 0.13 & -0.16 & 9.18 & 0.0001 & -0.002 \\
\hline Baton & St. Error & 0.52 & 0.004 & 0.15 & 1.9 & 0.29 & 0.4 & 1.16 & 0.32 & 0.07 & 1.02 & 0.07 & 0.07 & 0.34 & 0.05 & 0.001 \\
\hline Rouge & $\mathrm{R}^{2}$ & & 0.04 & & & 0.21 & & & 0.13 & & & 0.1 & & & 0.003 & \\
\hline \multicolumn{17}{|c|}{ White population } \\
\hline \multirow{3}{*}{ Orleans } & Estimate & 6.11 & -0.01 & -0.22 & 1.06 & -0.39 & 3.33 & 23.22 & 2.41 & -0.58 & 9.73 & -0.32 & -0.08 & 6.6 & -0.16 & -0.01 \\
\hline & St. Error & 0.36 & 0.003 & 0.1 & 1.22 & 0.18 & 0.26 & 1.95 & 0.54 & 0.12 & 1.15 & 0.08 & 0.08 & 0.21 & 0.03 & 0.001 \\
\hline & $\mathrm{R}^{2}$ & & 0.08 & & & 0.92 & & & 0.45 & & & 0.39 & & & 0.3 & \\
\hline \multirow{3}{*}{ Jefferson } & Estimate & 4.98 & -0.01 & 0.02 & 4.72 & -0.01 & 0.67 & 9.61 & 0.59 & -0.14 & 6.05 & -0.1 & -0.04 & 4.99 & -0.04 & -0.002 \\
\hline & St. Error & 0.24 & 0.002 & 0.07 & 0.83 & 0.12 & 0.17 & 0.72 & 0.2 & 0.05 & 0.51 & 0.04 & 0.03 & 0.15 & 0.02 & 0.001 \\
\hline & $\mathrm{R}^{2}$ & & 0.08 & & & 0.54 & & & 0.26 & & & 0.28 & & & 0.05 & \\
\hline \multirow{3}{*}{$\begin{array}{c}\text { East } \\
\text { Baton } \\
\text { Rouge }\end{array}$} & Estimate & 7.7 & -0.004 & 0.02 & 7.71 & -0.1 & -0.34 & 5.42 & -0.27 & 0.0004 & 6.02 & 0.02 & 0.01 & 7.08 & 0.03 & -0.001 \\
\hline & St. Error & 0.36 & 0.003 & 0.1 & 1.11 & 0.17 & 0.23 & 0.61 & 0.17 & 0.04 & 0.54 & 0.04 & 0.04 & 0.23 & 0.03 & 0.001 \\
\hline & $R^{2}$ & & 0.01 & & & 0.22 & & & 0.09 & & & 0.01 & & & 0.01 & \\
\hline
\end{tabular}




\section{References}

1. UN General Assembly. The Sendai Framework for Disaster Risk Reduction 2015-2030. Available online: http:/ / www.unisdr.org/files/43291_sendaiframeworkfordrren.pdf (accessed on 9 November 2018).

2. Sullivan, B.K. The Most Expensive U.S. Hurricane Season Ever: By the Numbers. Bloomberg Business 2017. Available online: https:/ / www.bloomberg.com/news/articles/2017-11-26/the-most-expensive-us-hurricane-season-ever-by-the-numbers (accessed on 9 November 2018).

3. Drye, W. Hurricane Katrina: The Essential Timeline. National Geographic 2005. Available online: URLhttps:/ / news.nationalgeographic.com/news/2005/09/weather-hurricane-katrina-timeline/ (accessed on 9 November 2018).

4. Johnson, D. Is This the Worst Hurricane Season Ever? Here's How It Compares. Time Magazine 2017. Available online: http:/ / time.com/4952628/hurricane-season-harvey-irma-jose-maria/ (accessed on 9 November 2018).

5. Schlegelmilch, J. Commentary: This Year's Hurricane Season Was the Costliest Ever. Now What? Fortune Magazine 2017. Available online: https://ncdp.columbia.edu/ncdp-perspectives/commentary-yearshurricane-season-costliest-ever-now / (accessed on 9 November 2018).

6. U.S. Department of Homeland Security. Ten Years after Katrina: FEMA Has Obligated over \$3.2 Billion in Public Assistance; Release Number: DR-1604-MS NR 789; U.S. Department of Homeland Security: Washington, DC, USA, 2015.

7. Cutter, S.L. There is no such thing as a natural disaster: Race, class, and Hurricane Katrina. J. Am. Plan. Assoc. 2008, 74, 264-265. [CrossRef]

8. Brunkard, J.; Namulanda, G.; Ratard, R. Hurricane Katrina deaths, Louisiana, 2005. Disaster Med. Public Health Prep. 2008, 2, 215-223. [CrossRef] [PubMed]

9. Blake, E.S.; Landsea, C.W.; Gibney, E.S. The Deadliest, Costliest, and Most Intense United States Tropical Cyclones from 1851 to 2010 (and Other Frequently Requested Hurricane Facts); Technical Memorandum NWS NHC-6; National Oceanic and Atmospheric Administration: Silver Spring, MD, USA, 2011; pp. 1-47.

10. Adams, V.; Kaufman, S.R.; van Hattum, T.; Moody, S. Aging disaster: Mortality, vulnerability, and long-term recovery among Katrina survivors. Med. Anthropol. 2011, 30, 247-270. [CrossRef] [PubMed]

11. Bourque, L.B.; Siegel, J.M.; Kano, M.; Wood, M.M. Weathering the storm: The impact of hurricanes on physical and mental health. Ann. Am. Acad. Political Soc. Sci. 2006, 604, 129-151. [CrossRef]

12. Bethel, J.W.; Burke, S.C.; Britt, A.F. Disparity in disaster preparedness between racial/ethnic groups. Disaster Health 2013, 1, 110-116. [CrossRef] [PubMed]

13. McCann, D.GC. A review of hurricane disaster planning for the elderly. World Med. Health Policy 2011, 3, 1-26. [CrossRef]

14. Cox, K.; Kim, B. Race and income disparities in disaster preparedness in old age. J. Gerontol. Soc. Work 2018, 61, 719-734. [CrossRef]

15. Arrieta, M.I.; Foreman, R.D.; Crook, E.D.; Icenogle, M.L. Providing continuity of care for chronic diseases in the aftermath of Katrina: From field experience to policy recommendations. Disaster Med. Public Health Prep. 2009, 3, 174-182. [CrossRef]

16. Ski, C.F.; King-Shier, K.M.; Thompson, D.R. Gender, socioeconomic and ethnic/racial disparities in cardiovascular disease: A time for change. Int. J. Cardiol. 2014, 170, 255-257. [CrossRef]

17. Nakamura, M.; Tanaka, F.; Nakajima, S.; Honma, M.; Sakai, T.; Kawakami, M.; Endo, H.; Onodera, M.; Niiyama, M.; Komatsu, T.; et al. Comparison of the incidence of acute decompensated heart failure before and after the major tsunami in Northeast Japan. Am. J. Cardiol. 2012, 110, 1856-1860. [CrossRef]

18. Aoki, T.; Fukumoto, Y.; Yasuda, S.; Sakata, Y.; Ito, K.; Takahashi, J.; Miyata, S.; Tsuji, I.; Shimokawa, H. The great East Japan earthquake disaster and cardiovascular diseases. Eur. Heart J. 2012, 33, 2796-2803. [CrossRef] [PubMed]

19. Aoki, T.; Takahashi, J.; Fukumoto, Y.; Yasuda, S.; Ito, K.; Miyata, S.; Shinozaki, T.; Inoue, K.; Yagi, T.; Komaru, T.; et al. Effect of the great East Japan earthquake on cardiovascular diseases-Report from the 10 hospitals in the disaster area. Circ. J. 2013, 77, 490-493. [CrossRef] [PubMed]

20. Swerdel, J.N.; Janevic, T.M.; Cosgrove, N.M.; Kostis, J.B.; Myocardial Infarction Data Acquisition System Study Group. The effect of Hurricane Sandy on cardiovascular events in New Jersey. J. Am. Heart Assoc. 2014, 3, e001354. [CrossRef] [PubMed] 
21. Jiao, Z.; Kakoulides, S.V.; Moscona, J.; Whittier, J.; Srivastav, S.; Delafontaine, P.; Irimpen, A. Effect of Hurricane Katrina on incidence of acute myocardial infarction in New Orleans three years after the storm. Am. J. Cardiol. 2012, 109, 502-505. [CrossRef] [PubMed]

22. Peters, M.N.; Moscona, J.C.; Katz, M.J.; Deandrade, K.B.; Quevedo, H.C.; Tiwari, S.; Burchett, A.R.; Turnage, T.A.; Singh, K.Y.; Fomunung, E.N.; et al. Natural disasters and myocardial infarction: The six years after Hurricane Katrina. Mayo Clin. Proc. 2014, 89, 472-477. [CrossRef] [PubMed]

23. Peters, M.N.; Katz, M.J.; Moscona, J.C.; Alkadri, M.E.; Khazi Syed, R.H.; Turnage, T.A.; Nijjar, V.S.; Bisharat, M.B.; Delafontaine, P.; Irimpen, A.M. Effect of Hurricane Katrina on chronobiology at onset of acute myocardial infarction during the subsequent three years. Am. J. Cardiol. 2013, 111, 800-803. [CrossRef] [PubMed]

24. Chui, K.K.; Webb, P.; Russell, R.M.; Naumova, E.N. Geographic variations and temporal trends of Salmonella-associated hospitalization in the U.S. elderly, 1991-2004: A time series analysis of the impact of HACCP regulation. BMC Public Health 2009, 9, 447. [CrossRef] [PubMed]

25. Erdman, E.; Liss, A.; Gute, D.M.; Rioux, C.; Koch, M.; Naumova, E.N. Does the presence of vegetation affect asthma hospitalizations among the elderly? A comparison between rural, suburban, and urban areas. Int. J. Environ. Sustain. 2015, 4, 1-14. [CrossRef]

26. Liss, A.; Wu, R.; Chui, K.K.; Naumova, E.N. Heat-related hospitalizations in older adults: An amplified effect of the first seasonal heatwave. Sci. Rep. 2017, 7, 39581. [CrossRef] [PubMed]

27. Chui, K.K.; Jagai, J.S.; Griffiths, J.K.; Naumova, E.N. Hospitalization of the elderly in the United States for nonspecific gastrointestinal diseases: A search for etiological clues. Am. J. Public Health 2011, 101, 2082-2086. [CrossRef]

28. Shaposhnikov, D.; Revich, B.; Gurfinkel, Y.; Naumova, E. The influence of meteorological and geomagnetic factors on acute myocardial infarction and brain stroke in Moscow, Russia. Int. J. Biometeorol. 2014, 58, 799-808. [CrossRef] [PubMed]

29. Shihadeh, E.S; Berthelot, E.; Weil, F.D.; Lee, M.R. Baton Rouge Welcomes Katrina Evacuees. 2006. Available online: https://www.lsu.edu/hss/sociology/research/CAPER/CAPER_Fact_Sheets/FS03.pdf (accessed on 9 November 2018).

30. U.S. Census Bureau. Methodology for the Intercensal Population and Housing Unit Estimates: 2000 to 2010. Annual National and State Housing Unit Estimates, Census Bureau 2012. Available online: https: / / www2.census.gov / programs-surveys/popest/technical-documentation/methodology / intercensal/2000-2010-intercensal-estimates-methodology.pdf (accessed on 9 November 2018).

31. Cleveland, W.S. Robust locally weighted regression and smoothing scatterplots. J. Am. Stat. Assoc. 1979, 74, 829-836. [CrossRef]

32. Metz, A. (Ed.) WGBH Education Foundation. 14 Days: A Timeline. Frontline. Available online: https://www.pbs.org/wgbh/pages/frontline/storm/etc/cron.html (accessed on 9 November 2018).

33. Brinkley, D. How New Orleans drowned. Vanity Fair Magazine 2006. Available online: https: / www.vanityfair.com/news/2006/06/brinkley_excerpt200606 (accessed on 9 November 2018).

34. Muggeo, V.M.R. Segmented: An R package to fit regression models with broken-line relationships. $R$ News 2008, 8, 20-25.

35. Naumova, E.N.; Must, A.; Laird, N.M. Tutorial in biostatistics: Evaluating the impact of 'critical periods' in longitudinal studies of growth using piecewise mixed effects models. Int. J. Epidemiol. 2001, 30, 1332-1341. [CrossRef] [PubMed]

36. Epel, E.S.; Lin, J.; Wilhelm, F.H.; Wolkowitz, O.M.; Cawthon, R.; Adler, N.E.; Dolbier, C.; Mendes, W.B.; Blackburn, E.H. Cell aging in relation to stress arousal and cardiovascular disease risk factors. Psychoneuroendocrinology 2006, 31, 277-287. [CrossRef]

37. Zarifeh, J.; Mulder, J. Natural Disasters and the Risk of Cardiovascular Disease. In Handbook of Psychocardiology; Springer: Singapore, 2015; pp. 1-20.

38. Tucker, P.; Pfefferbaum, B.; Jeon-Slaughter, H.; Khan, Q.; Garton, T. Emotional stress and heart rate variability measures associated with cardiovascular risk in relocated Katrina survivors. Psychosom. Med. 2012, 74, 160-168. [CrossRef]

39. Tucker, P.; Jeon-Slaughter, H.; Pfefferbaum, B.; Khan, Q.; Davis, N.J. Emotional and biological stress measures in Katrina survivors relocated to Oklahoma. Am. J. Disaster Med. 2010, 5, 113-125. [CrossRef] 
40. Kario, K.; McEwen, B.S.; Pickering, T.G. Disasters and the heart: A review of the effects of earthquake-induced stress on cardiovascular disease. Hypertens. Res. 2003, 26, 355-367. [CrossRef]

41. Sterling, P.; Eyer, J. Allostasis: A new paradigm to explain arousal pathology. In Handbook of life Stress, Cognition and Health; John Wiley \& Sons: Hoboken, NJ, USA, 1988; Chapter 34.

42. Brodie, M.; Weltzien, E.; Altman, D.; Blendon, R.J.; Benson, J.M. Experiences of hurricane Katrina evacuees in Houston shelters: Implications for future planning. Am. J. Public Health 2006, 96, 1402-1408. [CrossRef]

43. Davidson, T.M.; Price, M.; McCauley, J.L.; Ruggiero, K.J. Disaster impact across cultural groups: Comparison of Whites, African Americans, and Latinos. Am. J. Community Psychol. 2013, 52, 97-105. [CrossRef]

44. Moore, T. Institutional Barriers to Resilience in Minority Communities; Institute for Homeland Security Solutions: Durham, NC, USA, 2010.

45. Barnett, E.; Casper, M.L.; Halverson, J.A.; Elmes, G.A.; Braham, V.E.; Majeed, Z.A.; Bloom, A.S.; Stanley, S. Men and Heart Disease: An Atlas of Racial and Ethnic Disparities in Mortality. CDC Stacks 2001. Available online: https:/ / stacks.cdc.gov/view/cdc/ 49073 (accessed on 9 November 2018).

46. Barnett, E.; Casper, M.L.; Halverson, J.A.; Elmes, G.A.; Braham, V.E.; Majeed, Z.A.; Bloom, A.S.; Stanley, S. Women and Heart Disease: An Atlas of Racial and Ethnic Disparities in Mortality. CDC Stacks 2000. Available online: https:/ / stacks.cdc.gov / view / cdc/12169 (accessed on 9 November 2018).

47. Sharma, A.J.; Weiss, E.C.; Young, S.L.; Stephens, K.; Ratard, R.; Straif-Bourgeois, S.; Sokol, T.M.; Vranken, P.; Rubin, C.H. Chronic disease and related conditions at emergency treatment facilities in the new orleans area after Hurricane Katrina. Disaster Med. Public Health Prep. 2008, 2, 27-32. [CrossRef] [PubMed]

48. Mor, S.M.; DeMaria, A., Jr.; Naumova, E.N. Hospitalization records as a tool for evaluating performance of food- and water-borne disease surveillance systems: A Massachusetts case study. PLoS ONE 2014, 9, e93744. [CrossRef] [PubMed]

49. Chui, K.K.; Cohen, S.A.; Naumova, E.N. Snowbirds and infection-New phenomena in pneumonia and influenza hospitalizations from winter migration of older adults: A spatiotemporal analysis. BMC Public Health 2011, 11, 444. [CrossRef] [PubMed]

50. Tatsuki, S. Long-term life recovery processes among survivors of the 1995 Kobe earthquake: 1999, 2001, 2003, and 2005 life recovery social survey results. J. Disaster Res. 2007, 2, 484-501. [CrossRef]

(C) 2018 by the authors. Licensee MDPI, Basel, Switzerland. This article is an open access article distributed under the terms and conditions of the Creative Commons Attribution (CC BY) license (http:/ / creativecommons.org/licenses/by/4.0/). 